\title{
Geleneksel Ahşap Yapım Sistemlerinin Uygulamalar Üzerinden İncelenmesi
}

\author{
Z. Özlem PARLAK BIÇER ${ }^{1}$, Nurbanu ŞAHIIN ${ }^{1 *}$
}

Öz

Yapılar ve yapım sistemleri, bulundukları çevreye göre şekillenmektedir. Çevre koşulları ve kullanıcı tercihleri mekânsal düzenlemeleri etkilediği kadar taşıyıcı sistemleri ve malzeme seçimini de etkilemektedir. Dünyanın farklı bölgelerindeki yörelere ait, yerel mimari örnekleri görmek mümkündür. Geleneksel mimaride kullanılan malzemeler ise genellikle; yapının bulunduğu çevrede kolay ulaşılabilen, ucuz, işlenmesi kolay malzemelerdir. Bu malzemelerden biri olan ahşap, günümüze kadar geleneksel mimaride sıklıkla kullanılan yapı malzemelerindendir. Bitki örtüsünde sayıca fazla, dayanıklı ve yapım işlerinde kullanılabilecek nitelikte ağaçların olduğu bölgelerde konutlardan anıtsal yapılara kadar birçok yapı çeşidinde ahşap malzeme ve ahşap taşıyıcı sistemler kullanılmıştır. Bu çalışmada; dünyada kullanılan geleneksel ahşap yapım sistemleri, sistemlerin birbirleri ile olan benzerlikleri ve farklılıkları incelenmiştir. İnceleme yapılırken, UNESCO Dünya Miras Listesi'nde yer alan ve/veya bulunduğu ülkede nitelikli olarak kabul edilen yapılar çalışmaya konu olmuştur. Yapılan literatür araştırmasında konu üzerinde toplu olarak bir bilgi yerine parçalı çalışmalara ulaşılmıştır. Bu çalışmanın,yapı malzemesi olarak ahşap, yapım sistemi olarak ise ahşap taşıyıcı sistemler üzerine yapılan çalışmalara katkı sağlaması beklenmektedir.

Anahtar Kelimeler: Ahşap Yapım Sistemleri, Geleneksel Mimari, Geleneksel Ahşap Yapılar

\section{An Architectural Examination on Traditional Wooden Buildings Systems}

\begin{abstract} structural systems as building production system. Buildings

\footnotetext{
${ }^{1}$ Erciyes Üniversitesi, Mimarlık Fakültesi, Mimarlık Bölümü, Yapı Bilgisi Ana Bilim Dalı

*ilgili Yazar/ Corresponding author: nurbanusahinn@gmail.com

Gönderim Tarihi: 26.08 .2020

Kabul Tarihi: 21.12.2020
}

Buildings and building production systems are formed in respect to environmental factors in which they are located. Environmental factors and user preferences affect structural systems and selection materials as well as spatial organizations. It is possible to observe the peculiar examples of local architecture in different geographies in the world. Traditional architectural materials are generally easy to access and process and also cost-effective. Wood, as a traditional architectural material, has been frequently used in traditional architecture from past to present. Wooden architectural materials and structural systems are preferred in traditional houses and even monumental buildings in the regions where the landscape includes durable trees which are suitable for construction. This study examines the traditional wooden building systems including their similarities and differences with each other. The examples are selected from the UNESCO World Heritage List and/or registered as wooden architecture cultural heritage examples in different countries. This subject has not been examined with a holistic approach as a comprehensive research. However, there are some studies that dwell on this topic partially. Thus, this research is expected to contribute to the studies which examine the wood as a building material and wooden

Keywords: Wooden Structural Systems, Traditional Architecture, Traditional Wooden 


\section{GíRiş}

Mimari tasarım ve yapımda kullanılacak malzemeler, yapının inşa edileceği bölgenin; iklim, bitki örtüsü, ulaşım, ekonomi, kültür gibi şartlarından etkilenmektedir. Bu etkiler doğrultusunda; dünyanın her bölgesinde malzeme kullanımlarında, mimari akımlarda ve inşa edilen yapılarda farklılıklara rastlanmaktadır. Bu çeşitliliğin, mimari tasarımın bulunduğu yöreye özgü oluşunun göstergesi olduğu düşünülmektedir.

Geleneksel yapılar genellikle; inşa edildiği bölgenin yerel kaynakları dikkate alınarak tasarlanmıştır. Örneğin; Güney Amerika'da, Asya'nın güneyinde, Afrika'da yer alan ülkelerde geleneksel yapı malzemesi olarak kerpiç kullanılırken; ormanların yoğun, ağaçların nitelikli olduğu Avrupa, Kuzey Amerika ve Asya'da bulunan ülkelerde ise ahşap kullanılmıştır (Url-1, 2018).

Bu çalışmada farklı kıtalarda ve ülkelerde yer alan, UNESCO Dünya Miras Listesi'nde yer alan ve/veya bulunduğu bölgenin geleneksel ahşap mimari özelliklerini yansıtan yapılar üzerinden; dünyadaki ahşap malzeme kullanımı, geleneksel ahşap yapım sistemleri ve bu sistemler ile inşa edilmiş nitelikli yapıların malzeme ve taşıyıcı sistem özellikleri incelenmiştir. Çalışmanın amacı; dünyanın çeşitli bölgelerinde yer alan ahşap taşıyıcı sistemlerin farklarını, benzerliklerini ve birbirleri üzerindeki etkilerini görmektir.

\section{DÜNYADAN AHŞAP YAPI VE TAŞIYICI SISTEM ÖRNEKLERI}

Dünyanın farklı bölgelerinde koruma altında olan ahşap yapıların birbirlerinden farklı işlevlere sahip olduğu görülmektedir. Asya'da yer alan görkemli tapınaklar, ahşap İskandinav kiliseleri, Avrupa ve Anadolu'da yer alan konut, cami, kilise yapıları bunlara örnek olarak gösterilebilmektedir (Tokyay, 2017).

Aynı işleve ve ortak yapı malzemesine sahip yapılarda; tasarım kararları, malzeme kullanımı, yapım sistemleri yapının bulunduğu kıta, ülke ve bölgeye göre farklılık gösterebilmektedir (Larsen ve Marstein, 2016).

$\mathrm{Bu}$ çalışmada incelenen yapılar seçilirken; bulundukları bölgenin geleneksel ahşap mimarisini yansıtmalarına aynı zamanda, UNESCO ve/ veya bulundukları ülkelerce nitelikli yapı olarak kabul edilmiş yapılar olmalarına dikkat edilmiştir. Ülkelerin geleneksel ahşap yapım sistemlerinin benzerliklerinin, farklılıklarının ve etkileşimlerinin ortaya konulması amaçlandığı için; birbirine yakın konumda yer alan, kültür ve mimari biçimleniş olarak benzerlikler taşıyan ülkelerin yanında, aynı kıtada yer almasına rağmen farklı iklim ve coğrafi özellikleri bulunan ülkeler de incelenmiştir. Bu doğrultuda, orman yoğunluğunun yüksek olduğu Asya kıtasında yer alan; Nepal, Çin, Japonya, Kore, Rusya ülkelerindeki geleneksel ahşap mimarisi, tapınak ve konut yapıları üzerinden; Avrupa kıtasında yer alan; Finlandiya, Norveç, Almanya ülkelerindeki geleneksel ahşap mimarisi, kilise ve konut yapıları üzerinden; Afrika kıtasında yer alan; Etiyopya, Uganda ülkelerindeki geleneksel ahşap mimarisi, konut ve tapınak yapıları üzerinden; Amerika kıtasında yer alan; Kanada, Amerika Birleşik Devletleri, Şili, Brezilya ülkelerindeki geleneksel ahşap mimarisi, kilise ve konut yapıları üzerinden incelenmiştir (Harita 1). 


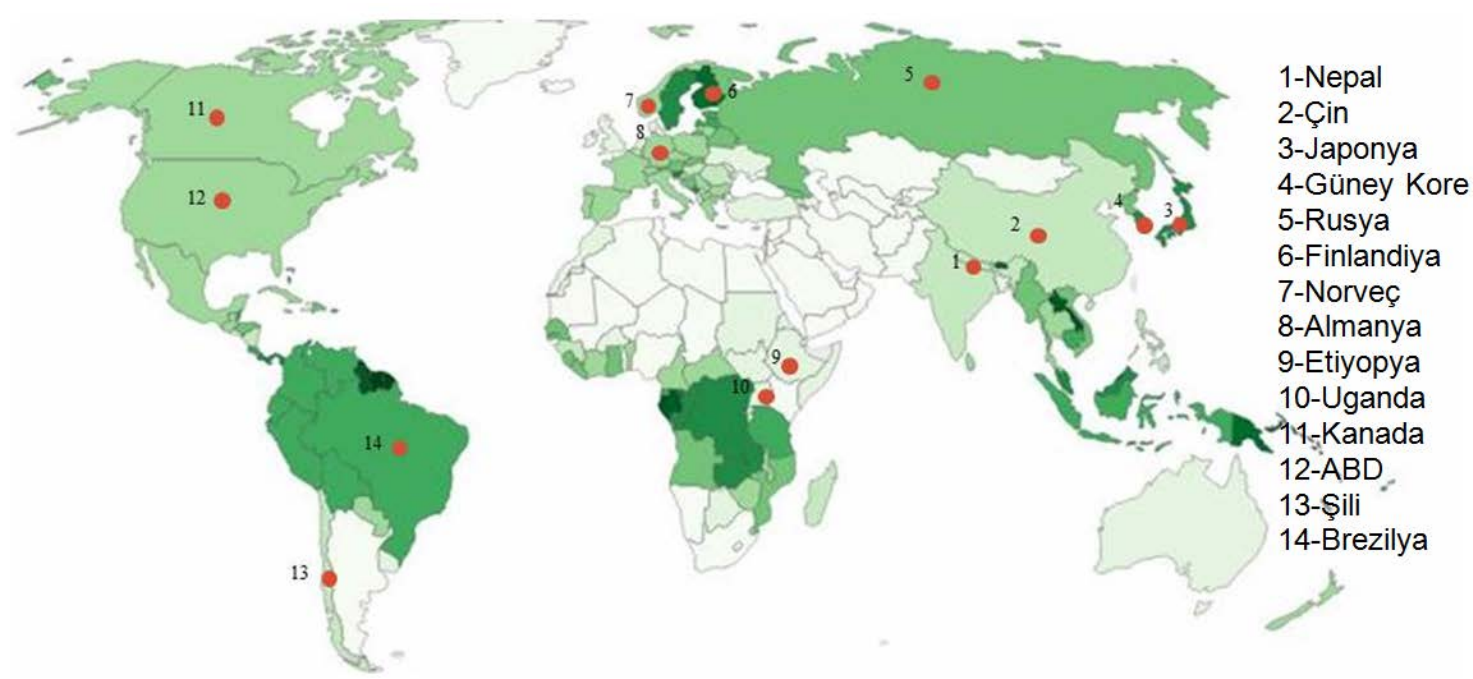

Harita 1: Ahşap yapıların incelendiği ülkeler (Roser,2017).

\subsection{Asya kıtası}

Ağaçların yüksekliğinin ve niteliğinin diğer kıtalara göre daha fazla olduğu Asya kıtasında, ahşap elemanlar mimaride sıklıkla kullanılmıştır. Kıtada yer alan ağaçların yükseklik, dayanıklılık vb. özellikleri; dünyanın en yüksek ahşap yapılarının Asya kıtasında yer almasına neden olmuştur (Banin vd., 2012; Que vd., 2017).

Asya kıtasında; Nepal, Çin, Japonya, Kore ve Rusya ahşap mimarisinde; özellikle anıtsal yapılar öne çıkmaktadır. Bu başlıkta; söz konusu ülkelerde kullanılan ahşap taşıyıcı sistem özellikleri UNESCO Dünya Miras Listesi'nde yer alan geleneksel ahşap yapılar üzerinden incelenmiştir (Harita 2).

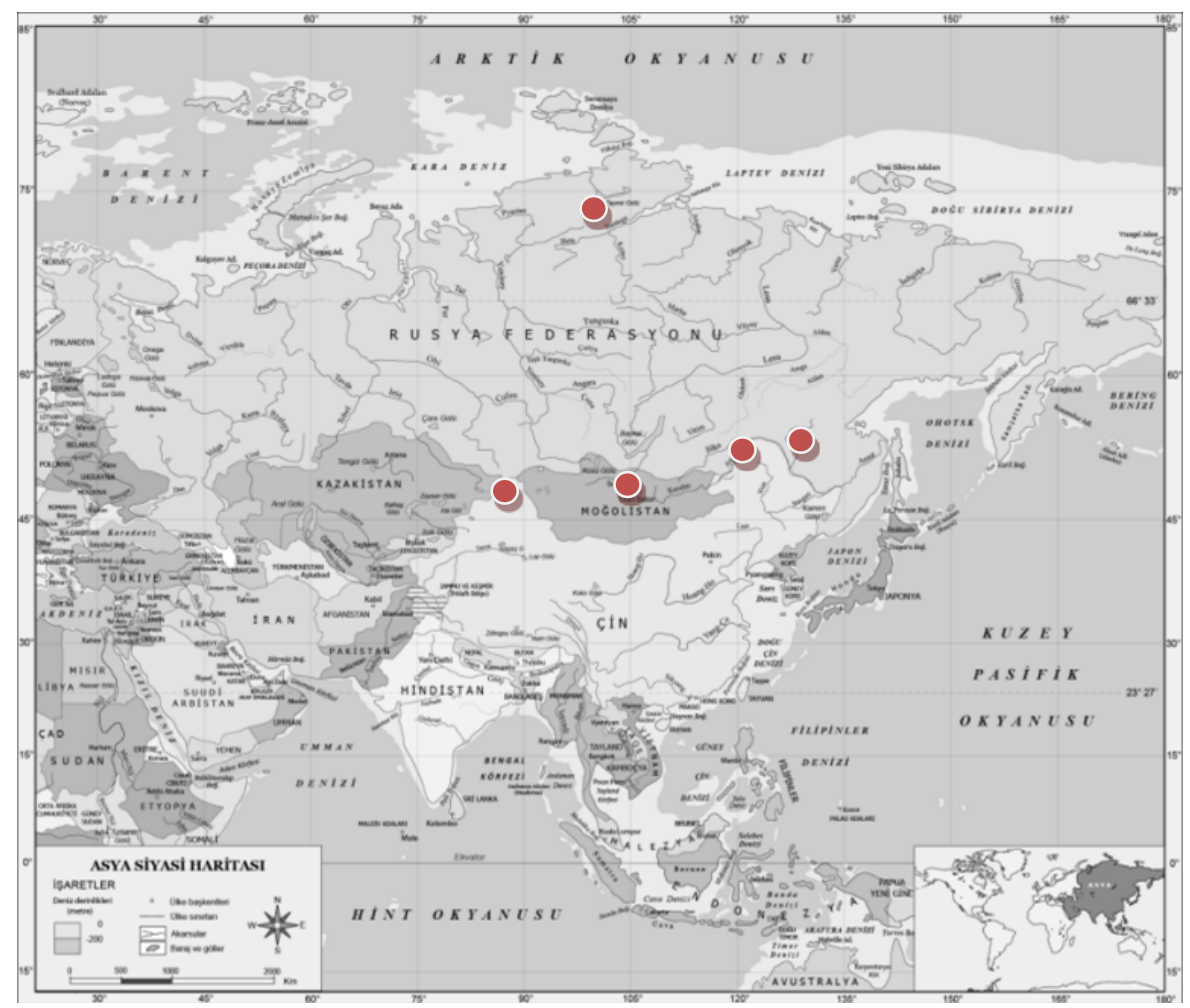

Harita 2: Asya'da ahşap yapıların incelendiği ülkeler (Url-2, 2019). 
Yapıların ele alındığı ilk ülke olan Nepal; değişken topografya özelliklerine sahiptir. Dünya'nın en yüksek dağı olan Everest Dağı'nın yer aldığı ülke olan Nepal'in coğrafyasındaki bu değişkenlik; iklimsel, kültürel ve ekonomik çeşitliliklere yol açarak geleneksel ahşap mimarisini de etkilemiştir (Bodacha vd., 2014).

Nepal'de yer alan tarihi alanların bulunduğu Katmandu vadisinde göl ve nehir yataklarından elde edilen kum vb. maddeler ile sık ormanlardan elde edilen ahşap malzemeler bina yapımında kullanılmıştır (Bodacha vd., 2014). Kentte, UNESCO Dünya Miras Listesi'nde yer alan yapılar ve meydanlar bulunmaktadır. Taş, tuğla ve ahşabın ortak kullanıldığı yapılar; ahşap iskelet sistem ile inşa edilmiştir. Yapılarda dikkat çeken diğer özellikler ise; cephe hareketleri, cephelerde yer alan yarı açık alanlar, ahşap sütunlar, çıkmalar, çatılar ve cephe süslemeleridir (Şekil 1-2) (Tokyay, 2017; Sharma ve Pokherel, 2017).

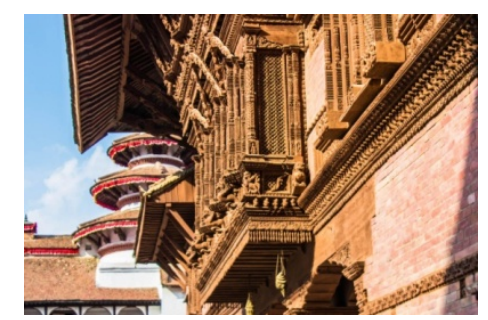

Şekil 1 : Ahşap pencere çıkması (Url-3, 2018).

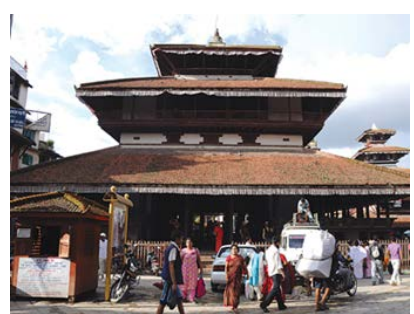

Şekil 2 2018).

Çin mimarisinde ise ülke topografyası ve karasal iklimden tropikal iklime kadar çeşitlilik gösteren iklim özellikleri nedeniyle; farklı bölgelerde bina tipolojileri ve yapım sistemlerinde farkıııklar ortaya çıkmıştır. Hızlı, pratik ve ağaç nitelikleri sayesinde dayanıklı olması nedeniyle Çin mimarisinde ahşap malzeme önemli yer tutmaktadır (Yamato, 2006). Çin ahşap mimarisi ise; sürekli çerçeve sistem, kirişli çerçeve sistem ve yığma sistem olmak üzere üç ayrı başlıkta incelenmektedir (Şekil 3) (Que vd., 2017).
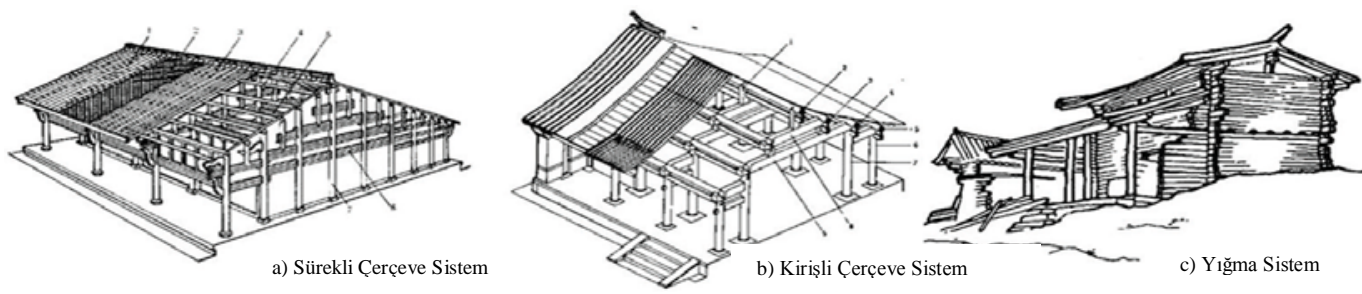

Şekil 3 : Geleneksel Çin ahşap mimarisinde yapım sistemleri.

Konutlardan tapınaklara kadar birçok yapıda ahşap kullanımı görülmektedir. Tapınak yapıları ise bölgede ahşabın ne kadar dayanıklı ve kuvvetli bir yapı malzemesi olduğunu kanıtlar niteliktedir. Bu yapılardan biri olan ve dünyadaki en yüksek ahşap yapı olduğu bilenen Yingxian Ahşap Pagodası, Çin mimarisinin en önemli özelliklerini yansıtmaktadır (Şekil 4-5) (Que vd., 2017). 


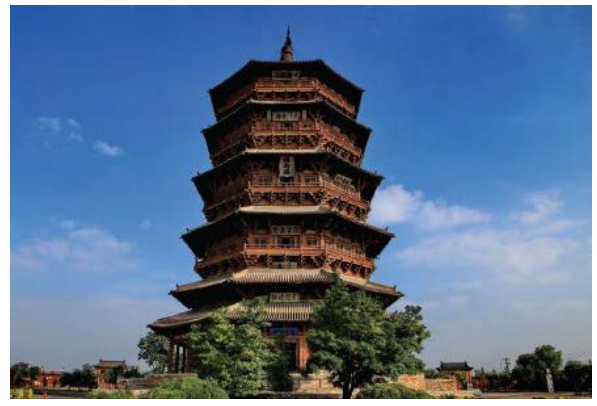

Şekil 4 : Yingxian Ahşap Pagodası (Que vd., 2017; Chen vd., 2014).

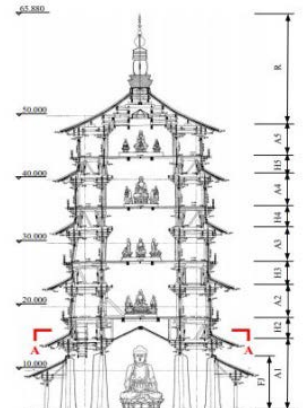

Şekil 5 :Yingxan Pagodası Kesit (Que vd., 2017; Chen vd., 2014).

Zengin ormanlara sahip Japonya'da da ahşap, önemli bir yapım elemanıdır (Yamato, 2006). Depremler ve şiddetli yağışların sıklıkla yaşandığı ülkede, mimari sistemler de bu etkenler doğrultusunda gelişmiştir (Ayverdi, 1967).

Ahşap taşıyıcı sistem ve ahşap yapım malzemeleri; yaklaşık $3.5 \mathrm{~m}^{2}$ alana sahip Tai-an çay odaları, tapınaklar, bazı endüstriyel yapılar, şehir içi ve kırsal bölgelerde yer alan konutlar gibi birçok yapı grubunda kullanılmıştır (Şekil 6) (Yamato, 2006). Japon geleneksel ahşap mimarisi ile Nepal ahşap mimarisi arasında benzerlikler de görülmektedir (Yamato, 2006).

Katmandu tapınaklarına benzerliği göze çarpan Japon tapınaklarının taşıyıcı sisteminde ahşap çerçeve sistem kullanılmıştır. Kolon ve kirişlerin bağlandığı noktalarda da ahşap elemanlar kullanılmış olan tapınaklarda, iç mekânlarda da dairesel kesitli kolonlar yer almaktadır (Şekil 7) (Yamato, 2006; Yasuhara ve Sakiyama, 2006).

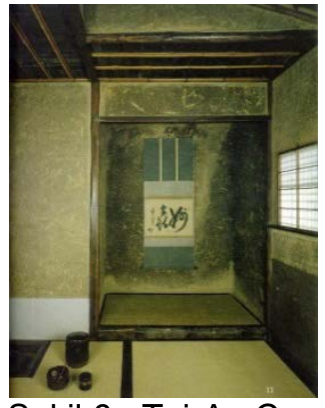

Şekil 6 :Tai-An Çay

Odası (Url-5, 2018)
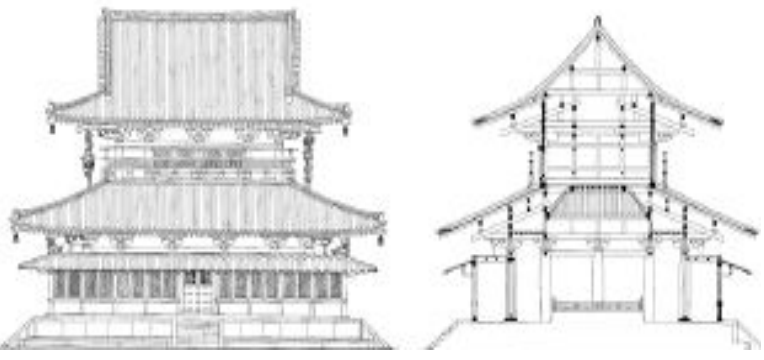

Şekil 7 :Horyuji Tapınağı Ana Mekân (Yasuhara ve Sakiyama, 2006).

Japon geleneksel konut mimarisinde de ahşap çerçeve sistem kullanılmıştır. Kolon ve kirişlerden oluşan çerçeve sistemin yanal etkiler karşısında sabit kalması beklenmektedir. Ahşap malzeme de deprem anında; belirli oranda esneyebildiği ve darbeleri sönümleyebildiği için deprem kuşağında yer alan Japonya'da yaygın olarak tercih edilmektedir. Ahşap konut yapıların bir başka önemli özelliği ise; geri dönüşüme açık olmasıdır. Yapı elemanlarına zarar verilmeden, taşıyıcılar sökülüp yeniden monte edilebilmektedir (Şekil 8) (Yamato, 2006; Yasuhara ve Sakiyama, 2007). 


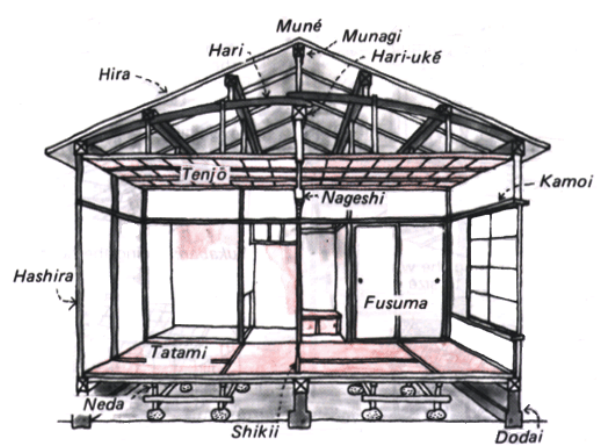

Şekil 8 : Geleneksel Bir Ahşap Japon Evi Kesit (Tokyay, 2017).

Doğa, mimari ve insanı tek bir varlık olarak kabul eden Kore öğretileri, kültürel mirasın korunması ve geleneksel mimari ögeler konusunda en önemli etkenlerden olmuştur (Kim, 2006; Radzuan vd., 2013).

Hanok olarak adlandırılan geleneksel Kore evleri; doğa, iklim, kültürel özellikler ve halkın günlük alışkanlıkları, geleneksel malzeme ve yapım teknikleri kullanılarak inşa edilmiştir (Cho, 2013). Geleneksel Hanok yapılarına örnek olan yapıların bulunduğu Hahoe ve Yangdong tarihi köyleri UNESCO tarafından da koruma altındaki alanlar olarak değerlendirilmektedir (Şekil 9-10) (Choi, 2003; Url-6, 2018). Subasmanı taş malzemeden inşa edilen yapıların taşıyıcı sistemi ahşap kolon ve kirişlerden oluşan çerçeve sistemdir. Duvarlarda ahşap çerçeve sistem arası dolgu bulunan konutlarda çatıda ve kapı pencere doğramalarında da ahşap malzeme kullanılmıştır (Cho, 2013).

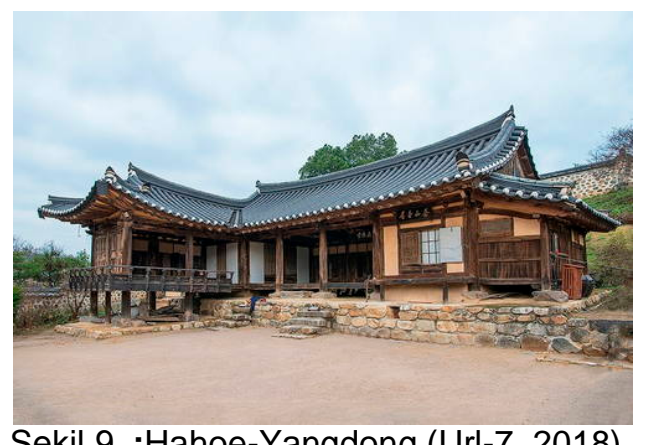

Şekil 9 :Hahoe-Yangdong (Url-7, 2018).

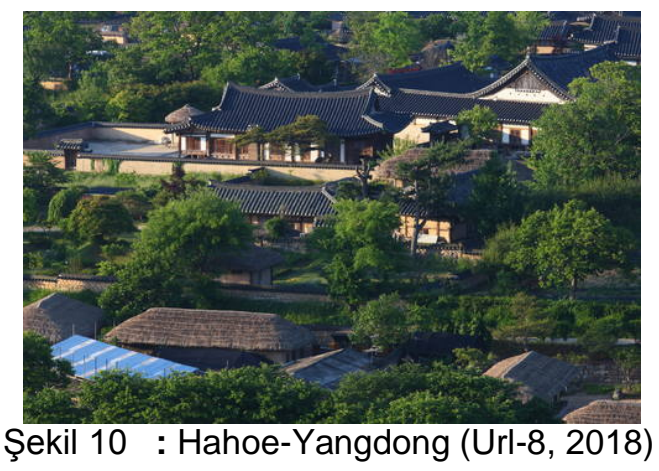

Dünyanın yüz ölçümü en büyük ülkesi olan Rusya'da yer alan ormanlar küresel orman hacminin yaklaşık \%25'ini oluşturmaktadır (Url-9, 2020). Ormanların yoğunluğu ve ağaçların niteliği, ahşabın yapı malzemesi olarak kullanımını da yaygın hale getirmiştir. Rusya'ya özgü kırsal konutlar olan “izba”larda ve tuğla, taş malzemenin yetersiz olduğu Rusya'nın kuzey kesimlerinde yer alan kiliselerde ve diğer yapılarda da ahşap malzeme; taşıyıcı sistemlerde, cephelerde, doğramalarda, çatılarda ve süslemelerde kullanılmıştır (Şekil 11) (Voyce, 1957; Khodakovsky, 2015; Brumfield, 2016; Mainicheva,2018).

Kırsal kesimlerde inşa edilen evlerden sonra 19. yy'da şehir merkezlerinde de, kırsal konutların geleneksel mimari özelliklerini yansıtan konut ve hizmet binaları inşa edilmiştir. Ahşap, tuğla ve taş malzemenin birlikte kullanıldığı yapılarda taşıyıcı sistem, ahşaptır (Şekil 12) (Voyce, 1957; Brumfield, 2016). 


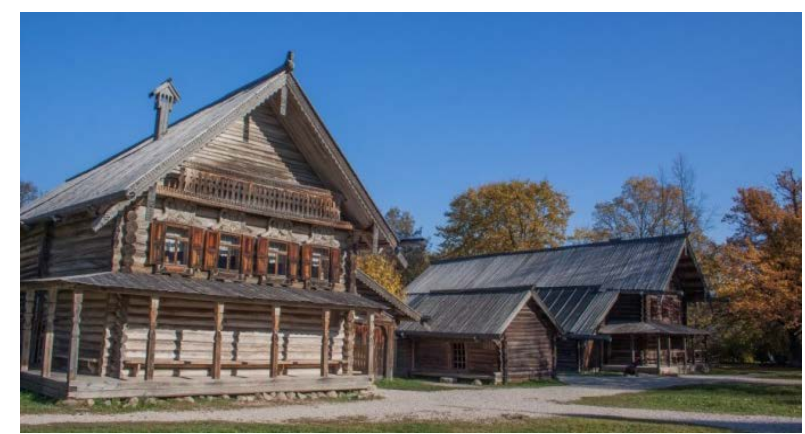

Şekil 11 : Vitoslavlitsy Açık Hava Müzesi (Url-10, 2020)

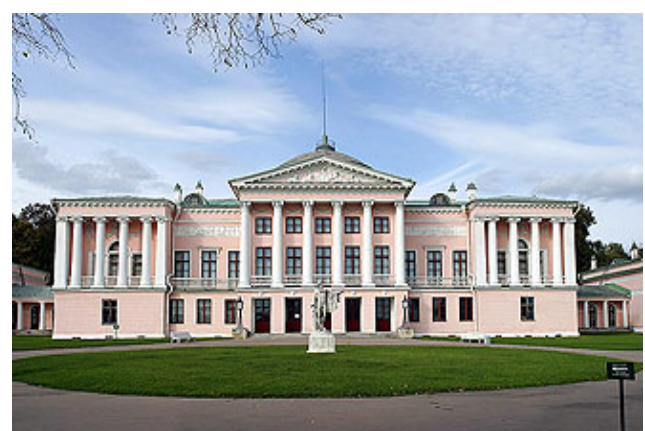

Şekil 12 : Ostankino Sarayı (Url-11, 2020).

Kiliselerde de ahşap malzeme ve ahşap taşıyıcı sistem kullanıımıştır. Kizhi Açık Hava Müzesi içinde Kizhi Pagost'un da yer aldığı birbirinden farklı işlevlere sahip 80 ahşap yapı bulunmaktadır (Kisternia, 2018; Url-12, 2020). Yaz kilisesi, kış kilisesi ve çan kulesi üçlü yapılarından oluşan Kizhi Pagost; ahşap taşıyıcı sistem ve ahşap malzeme kullanımının en güçlü örneklerinden biridir. Yapının tamamı çivi kullanılmadan ahşapların birbirine geçirilmesi ile yığma olarak inşa edilmiştir (Şekil 13-14)(Kisternia, 2018; Url-12, 2020).

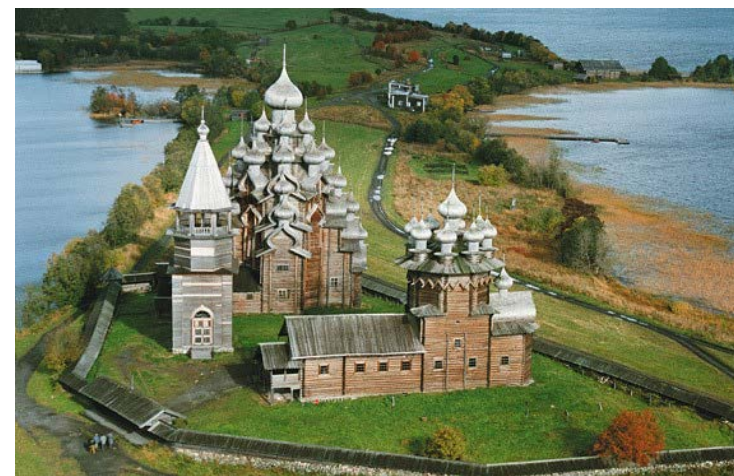

Şekil 13 : Kizhi Pagost (Url-13, 2020)

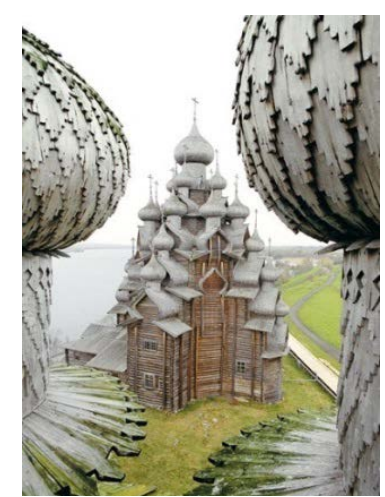

Şekil 14 : Kizhi Pagost (Url-13, 2020)

\subsection{Avrupa kıtası}

Orman yoğunluğu ve ahşap kullanımı konusunda Asya'dan sonra Avrupa kıtası gelmektedir (Url-14, 2018; Sangiorgi, 2008). Gotik ve Barok mimari dönemlerinde taş yapıların görüldüğü Avrupa'da, ahşap konut ve kilise yapıları da bulunmaktadır (Tokyay, 2017). Avrupa kıtasında; farklı iklim, yerel kaynak ve coğrafi özelliklerin görüldüğü ülkelerde farklı yapım sistemlerine rastlamak mümkündür.

Avrupa kıtasında, ahşap mimarisinde öne çıkan; Finlandiya, Norveç ve Almanya ülkelerinin ahşap yapım sistemleri ile bu ülkelerde yer alan ve ülkelerin ahşap mimarisi özelliklerini taşıyan yapılardan UNESCO Dünya Miras Listesi'nde bulunan yapılar incelenmiştir (Harita 3). 


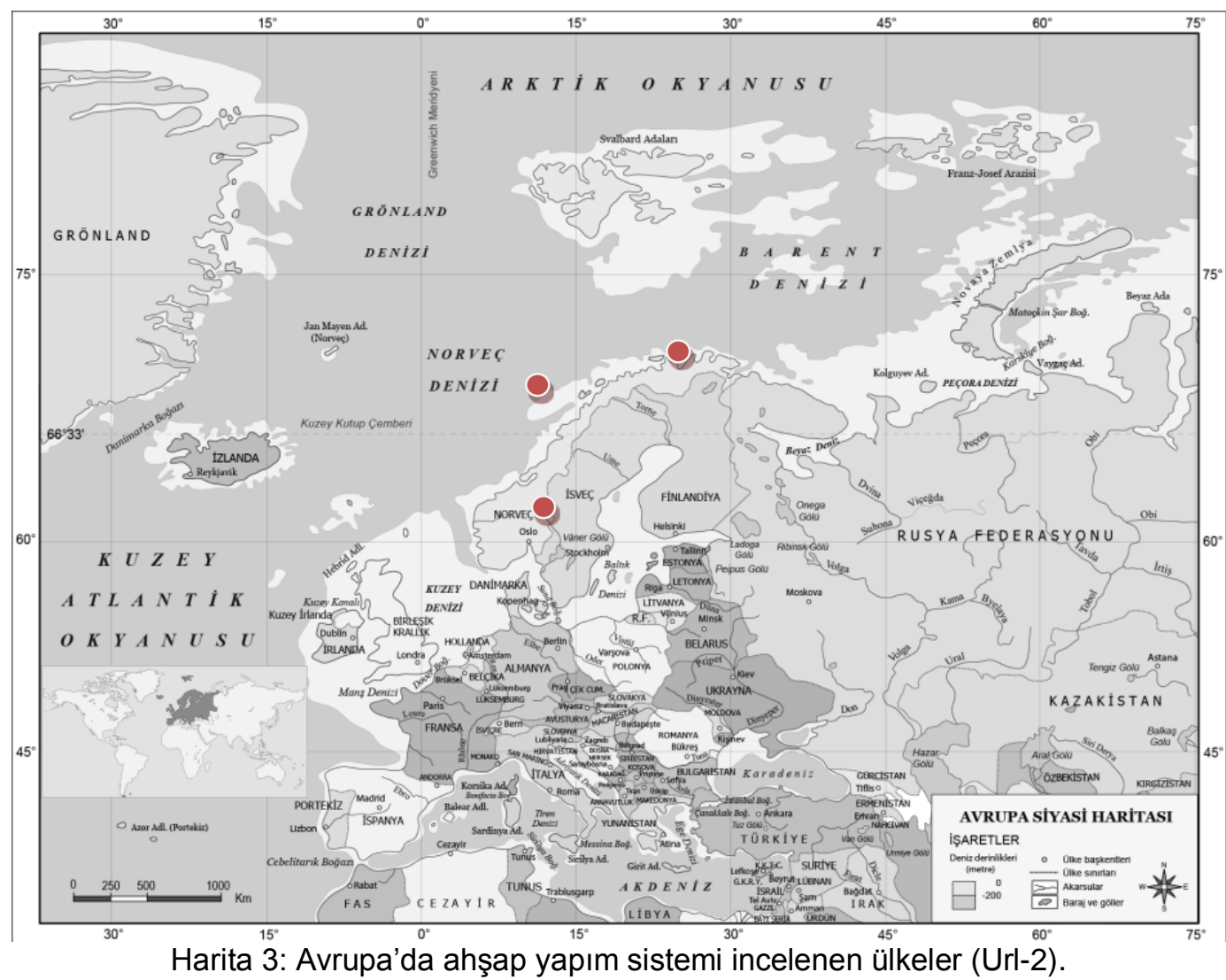

Ağaç yoğunluğunun çok fazla olduğu bir ülke olan Finlandiya'da ilk olarak tekil konut yapılarında ahşap malzeme kullanılmış daha sonra ahşap konutların artması sokak dokularının oluşmasına neden olmuştur. Küçük ölçekli konut yapıların kullanılan ahşap malzeme; kiliseler gibi anıtsal yapılarda da kullanılmıştır (Peters, 2006; Heikkila, 2005). Finlandiya'da görülen ahşap yapım sistemlerini Ortaçağ kökenli eski yapım sistemi ve 19. yüzyılın başlarında kullanılmaya başlayan yeni yapım sistemi olarak iki başlıkta incelemek mümkündür (Peters, 2006; Heikkila, 2005).

Ortaçağ kökenli eski yapım sisteminde; ahşap elemanların birbirine geçmesi ile oluşturulmuş duvarlar taşıyıcı görevi görmektedir. Taş temele oturtulan yapılarda; ahşap elemanlar arasındaki boşluklar bitkisel malzemeler ile doldurulmuştur (Şekil 15) (Peters, 2006; Heikkila, 2005, Url-15, 2018). 19. yüzyıl'da kullanılmaya başlanan yeni yapım sisteminde ise; endüstriyel olarak elde edilen ahşap elemanlar sayesinde daha büyük ölçekli yapılar inşa edilebilmektedir (Şekil 16) (Peters, 2006; Heikkila, 2005, Url15, 2018).

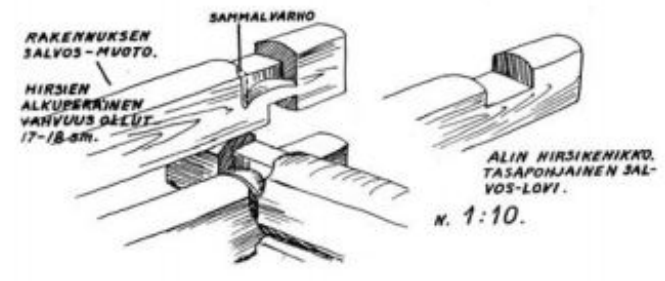

Şekil 15 : Finlandiya'da Ahşap Yapım Eski Sistem (Url-16, 2018).

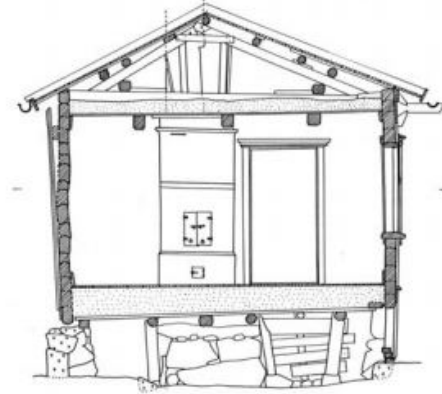

Şekil 16 : Finlandiya'da Ahşap Yapım Yeni Sistem (Url-16, 2018). 
Tarihi Fin şehirlerinde ahşap cadde boyunca yer alan ahşap yapıların oluşturduğu sokak dokusu da Finlandiya'nın mimari simgelerinden olmuştur. Sokağa açılan yüksek kapılardan evlerin iç mekânında yer alan özel avlulara ulaşılmaktadır (Tokyay, 2017; Peters, 2006; Url-15, 2018).Finlandiya'nın en eski şehirlerinden biri Botnia'da bir liman kasabası olan Rauma da geleneksel sokak dokusunun görüldüğü kasabalardan biridir. Geleneksel ahşap kasabaları temsil etmesi nedeniyle UNESCO Dünya Mirası Listesi'nde yer almaktadır (Şekil 17-18) (Peters, 2006).

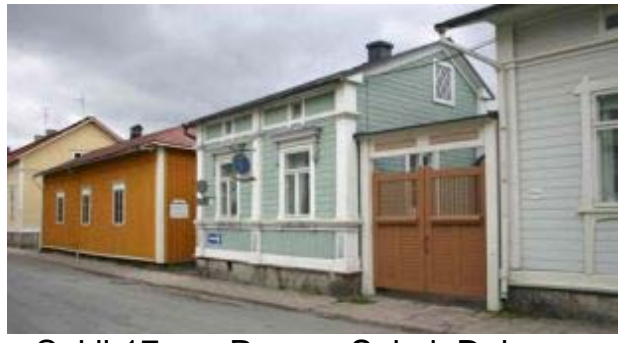

Şekil 17 : Rauma Sokak Dokusu.

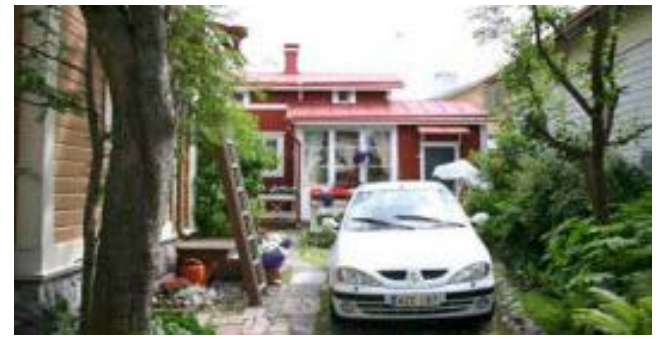

Şekil 18: Rauma Evleri.

Finlandiya'da iğne yapraklı ağaçların sıklıkla bulunduğu bir bölgede yer alan Petäjävesi Eski Kilise; Kuzey Avrupa ahşap kiliselerinin özelliklerini yansıtmaktadır. Rönesans ve Gotik mimari akımlarından etkilenilerek tasarlanan cephesinin aksine; kilisede yapım sistemi olarak, geleneksel ahşap taşıyıcı sistem uygulanmıştır (Url-16, 2018; Suominen-Kokkonen, 2016; Url-17, 2018). Çapraz tonozlu ahşap bir kubbeye sahip olan yapıda bu sistem cepheye yansımamıştır. Bu tasarım ile özel bir örnek olan kilise; elemanların birbirine eklemlenmesini kolaylaştırdığı için ahşap yapım sistemlerine en uygun plan tiplerinden biri olan haç plan tipinde inşa edilmiştir (Şekil 19-20) (Soikkeli ve Koiso-Kanttila, 2006).

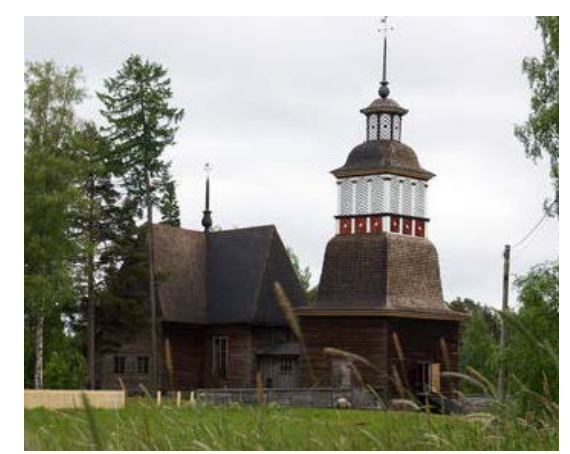

Şekil 19 : Petäjävesi Eski Kilise (Url-18, 2018).

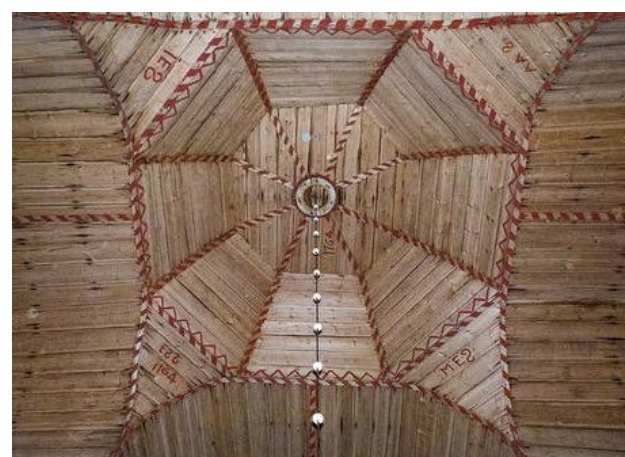

Şekil 20 :Petäjävesi Eski Kilise Kubbe (Url-19, 2018).

Norveç; ağaç yoğunluğunun fazla olması, iklim, ekonomi ve geleneksel tasarım bilgileri nedeniyle ahşap yapım sistemlerinin sıklıkla görüldüğü bir ülkedir (Bye, 2010; Espedal, 2017). Ahşabın doğal yalıtım özellikleri, kolay işlenen ve ucuz bir yapı malzemesi olması Norveç'te ahşabın tercih edilme sebeplerindendir (Espedal, 2017). Norveç ahşap mimarisinin bir diğer önemli özelliği ise; dünyanın birçok ülkesinde görülenin aksine, ahşap yapılardaki mimari formların taş ya da tuğla ile inşa edilmiş yapılardan etkilenmesidir (Larsen ve Marstein, 2017).

Dünyanın örgütlü ilk ticari birliği olan Hansa Birliği'ne ait bir ticaret şehri Bergen şehrindeki Bryggen bölgesinde nehir kenarında bulunan ahşap binalar cephe kaplamaları ile Norveç ahşap mimarisinin özelliklerini yansıtmaktadır (Şekil 21)(Aytüre vd., 2017). Bu özellikleri nedeniyle Hansa Binaları UNESCO Dünya Mirası Listesi'nde yer almaktadır (Url-20, 2018). 


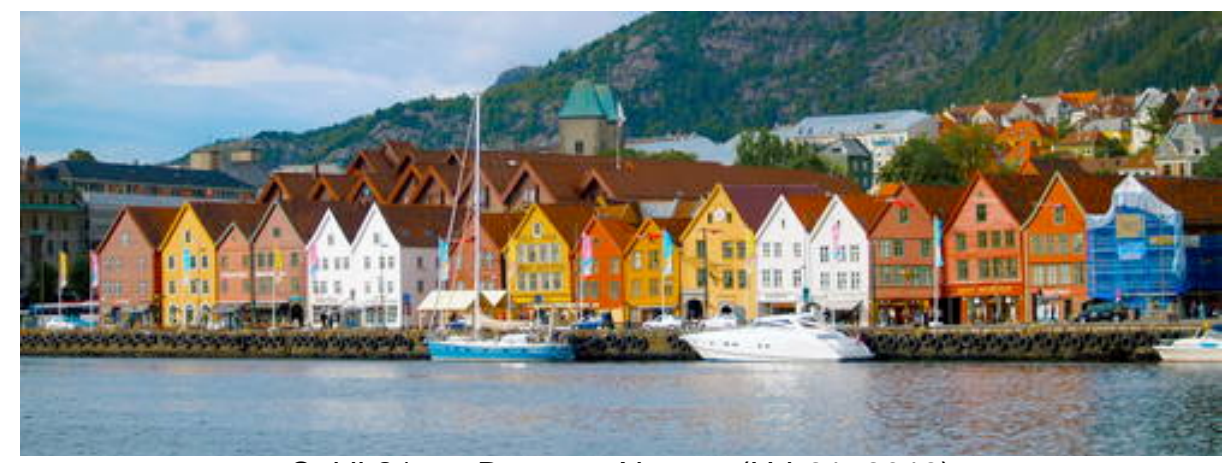

Şekil 21 : Bryggen-Norveç (Url-21, 2018)

Norveç geleneksel ahşap mimarisinin diğer bir önemli unsuru ise; Neolitik dönemden Ortaçağ'a kadar gelen kütük kiliselerdir (Url-22, 2018). Avrupa mimarisinin en büyük miraslarından olarak kabul edilen bu kiliselerin 28 tanesi Norveç'te bulunmaktadır (Espedal, 2017).

Avrupa'da yer alan en önemli kütük kiliselerden biri olan Norveç Urnes Stave Kilisesi; kübik başlıklar, kemerler ve silindirik sütunların kullanıldığı, Romanesk taş mimarisinin ahşap malzeme ile inşa edilmiş örneklerinden bir tanesidir (Şekil 22-23)(Url-22, 2018).

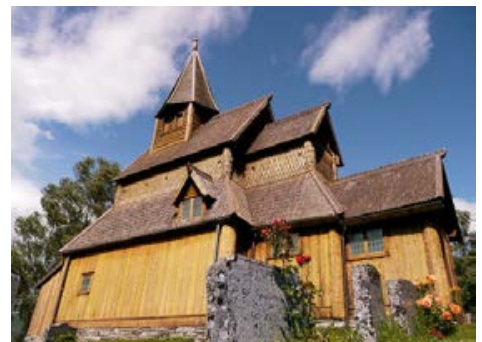

Şekil 22 : Urnes Stave Kilisesi (Url-23, 2018).

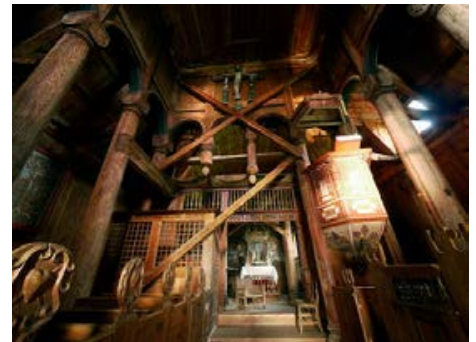

Şekil 23 : Urnes Stave Kilisesi İç Mekân (Url-24, 2018).

Avrupa kıtasının ağaç potansiyeli en yüksek ülkesi ise; yüz ölçümünün yaklaşık \%30'u ormanlık alan olan Almanya'dır (Url-25, 2018). Modern üretim sistemleri ile günümüzde de ahşap yapıların kullanımının artırılmaya çalışıldığı Almanya'da geleneksel ahşap mimari ile inşa edilmiş, Dünya Miras Listesi'nde yer alan yapılar da bulunmaktadır.

Alman geleneksel ahşap karkas sistemi (Fachwerkkonstruktion), nadiren de olsa halen kullanılmakta olan bir yapım sistemidir. Fachwerk; payandalar ile desteklenen yatay kirişlerden oluşan bir ahşap çerçeve sistemidir. Bu çerçeve içerisinde kil ya da taş malzemeler ile dolgu yapılmaktadır (Şekil 24-25) (Url-26, 2018).

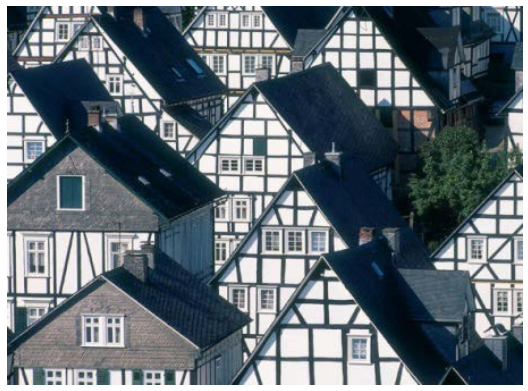

Şekil 24 :Fachwerk Yapım Sistemi (Url-27, 2018)

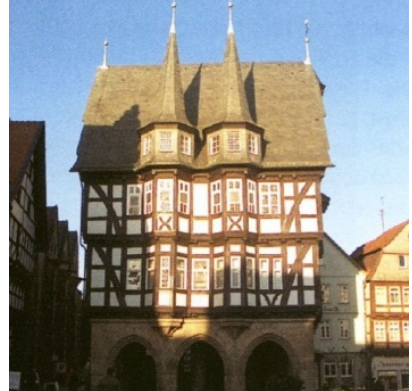

Şekil 25 :Alsfeld Belediye Binası (1512) (Bilici, 2006) 
Almanya'da yer alan Quedlinburg şehrinde; 1620-1720 yıllarında inşa edilmiş birçok Fachwerk yapı bulunmaktadır (Şekil 26) (Url-25, 2018). Quedlinburg şehrini Dünya Miras Listesi'ne dahil eden üç ana unsur; Ortaçağ sokak dokusunun korunması, 16.-17. yy ahşap iskeletli evleri ve St Servatius kilisesi olarak belirtilmiştir (Şekil 27) (Url-25, 2018).

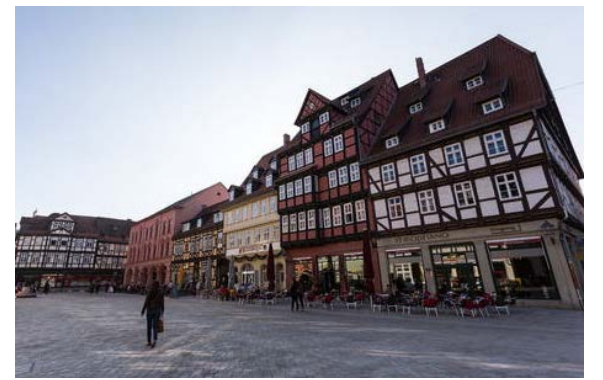

Şekil 26 : Quedlinburg Şehri (Url-28, 2018).

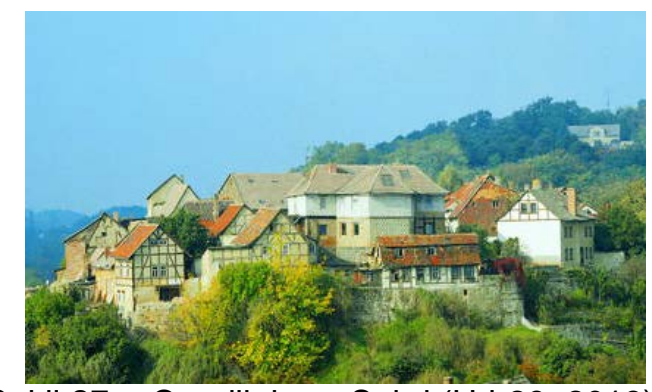

Şekil 27 : Quedlinburg Şehri (Url-29, 2018).

\subsection{Afrika kıtası}

Ağaç boyları ve yoğunluğu bakımından Asya ile benzerlikler taşıyan Afrika'da, gelişen teknolojiye uyum sağlayamadığı için ilkel olarak kabul edilen geleneksel yapılar bulunmaktadır (Banin vd., 2012). Yerel ve doğal malzemeler kullanılarak inşa edilen yapılar sürdürülebilir mimari örnekleri olarak değerlendirilmektedir (Ejiga vd., 2012).

Afrika kıtasında; geleneksel ahşap mimarisinin özelliklerini taşırken aynı zamanda da kendine has özellikleri olan, UNESCO Dünya Miras Listesi'nde de bulunan, Etiyopya'nın Harar Jugol kasabasındaki ahşap yapım sistemleri ve kasabada bulunan ahşap yapılar ile Uganda'da yer alan geleneksel evler ve Kasubi Mezarları incelenmiştir (Harita 4).

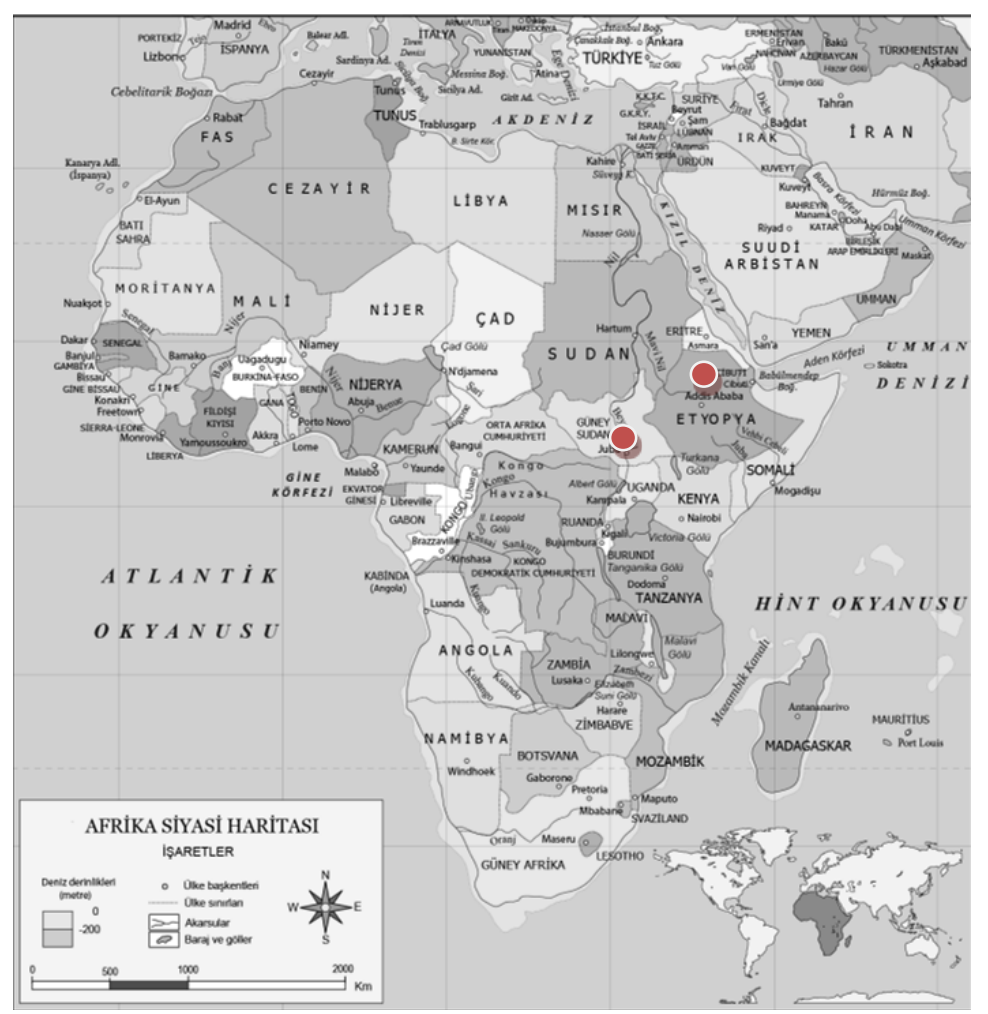

Harita 4: Afrika'da ahşap yapım sistemi incelenen ülkeler (Url-2, 2018). 
Afrika'nın geleneksel mimari yapılarında; taş ve toprak malzemeden daha kolay ulaşıllabilen ahşap ve saman birlikte kullanılmaktadır. Saman ve kerpiç ise ahşap taşıyıcı sistemlerde dolgu malzemesi olarak tercih edilmektedir (Şekil 28-29) (Ejiga, 2012).
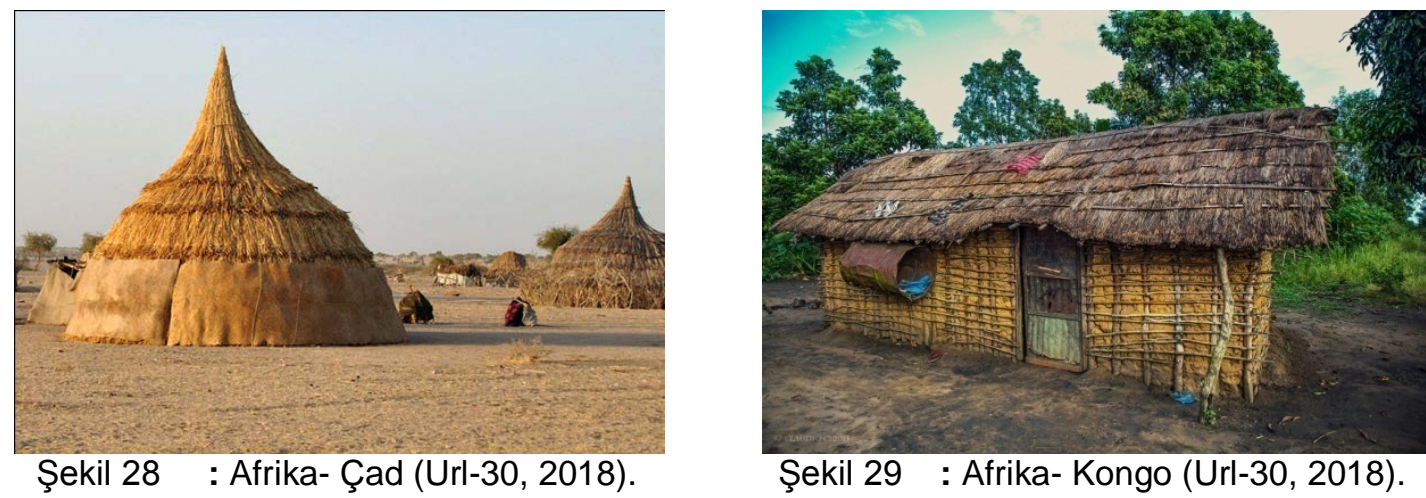

Yağış ve sıcaklık miktarlarının fazlaca değişkenlik gösterdiği Etiyopya'da; toprakların \%10 - \%15'lik bir kısmını kaplayan ormanlar son yıllarda yok olma tehlikesi ile karşı karşıyadır (Surur Sany, 2015).

Etiyopya'da yer alan Harar Jugol şehrinin mimari mirasının önemli bir bölümünü oluşturan Harar evlerinde ahşap; tavan kaplamalarında, yer döşemelerinde, kapılarda, pencerelerde, korkuluklarda, kimi evlerde ise cephelerde ve özellikle iç mekânlarda kullanılmıştır (Şekil 30-31) (Surur Sany, 2015; Url-31, 2018).

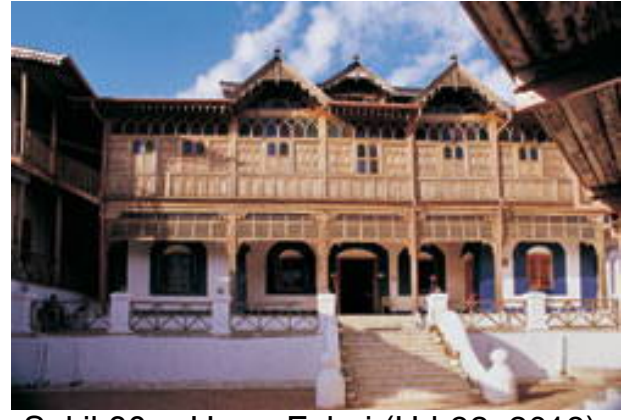

Şekil 30 : Harar Evleri (Url-32, 2018).

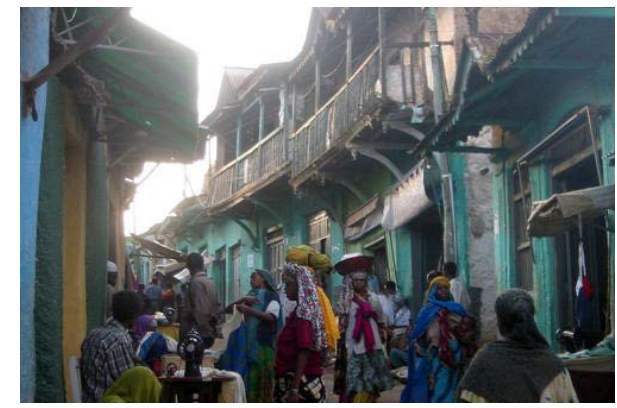

Şekil 31 : Harar Evleri (Url-33, 2018).

Tropikal iklime sahip bir kara ülkesi olan Uganda'nın yoğun yağış alan bölgelerinde sık ormanlar bulunmaktadır (Griffin vd., 2019) Bu durum geleneksel yapılarda ahşap çerçeve sistem ve kerpiç dolgu kullanılmasına neden olmaktadır (Griffin vd., 2019; Url$34,2020)$.

Kırsal bölgede yer alan geleneksel evlerdeki taşıyıcılarda; ahşap çerçeve sistem, duvarlarda kerpiç ve çatılarda ise bölgede yetişen kamış vb. bitkisel malzemeler kullanılmaktadır (Şekil 32-33) (Griffin vd., 2019; Url-34, 2020). 


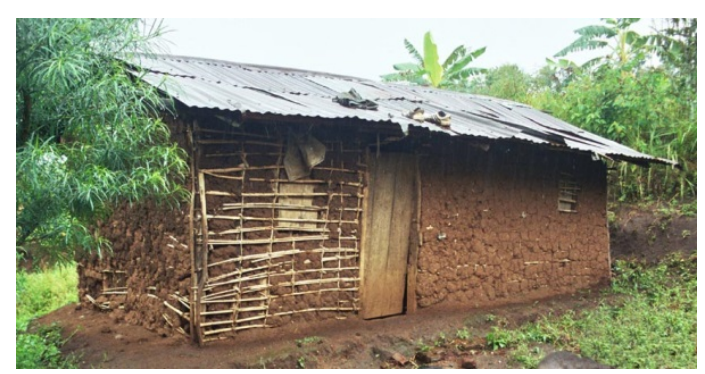

Şekil 32 : Uganda Ev (Url-34, 2020).

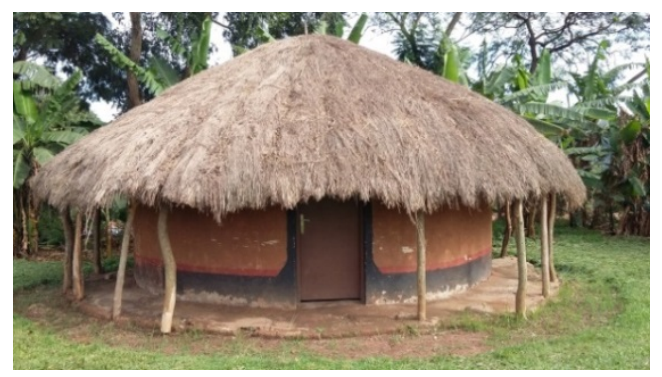

Şekil 33 : Uganda Ev (Url-35, 2020).

Uganda'nın güneyinde yer alan özerk bir bölge olan Buganda'da ise Uganda'nın UNESCO dünya mirası listesinde yer alan Kasubi Mezarları bulunmaktadır (Kigongo ve Reid, 2007; Url-36, 2020).

Mezarların bulunduğu bölge; yaklaşık 35 hektarlık bir alanı kaplamaktadır (Şekil 34) (Kigongo ve Reid, 2007).Birden fazla mezar ve kültürel değere sahip olan yapıların bulunduğu alanda yer alan başlıca yapılar; Bujjabukula, Obukaba (Davul Evi) ve Muzibu-Azaala-Mpanga'dır (Kigongo ve Reid, 2007; Url-37, 2020).

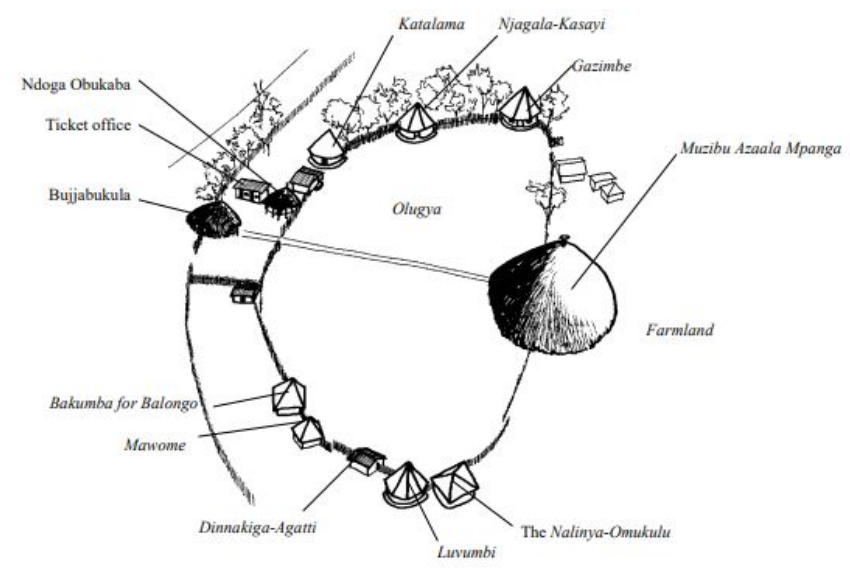

Şekil 34 : Kasubi Mezarları (Url-36, 2020).

Yapımında bitkisel malzemeler kullanılan yapılarda; taşıyıcı olarak ahşap kolonlar ve çatılar ile saz, kamış vb. maddeler kullanılarak inşa edilmiş duvarlar bulunmaktadır (Şekil35-36) (Kigongo ve Reid, 2007; Url-36, 2020).

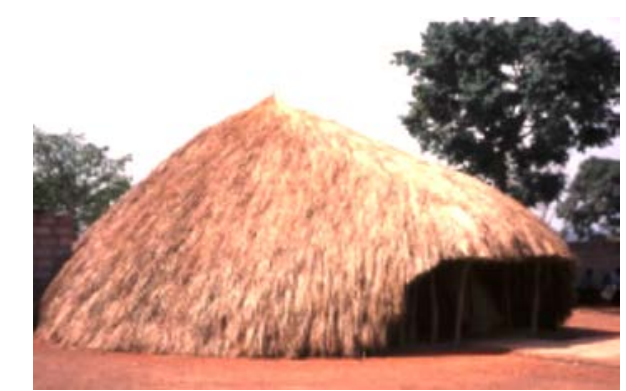

Şekil 35 :Bujjabukula (Url-36, 2020)

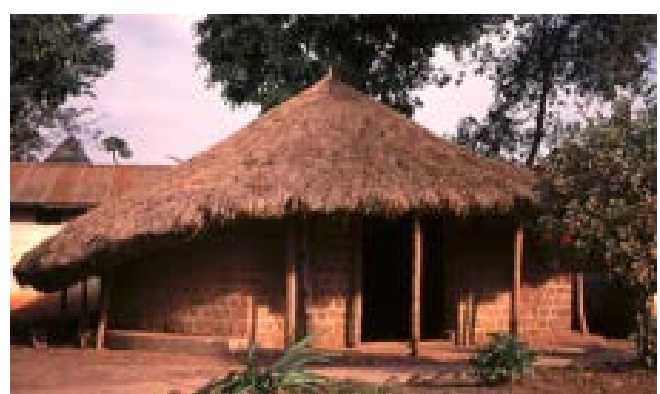

Şekil 36 :Ndoga-Obukaba (Url-36, 2020)

1882 yılında inşa edilen ana mezar; Muzibu-Azaala-Mpanga'nın yapımında da aynı teknik kullanılmıştır. Taşıyıcı sistemi ahşap kolonlar ile oluşturulmuş ve diğer bitkisel elemanlar kullanılarak da duvarları ve çatısı inşa edilmiştir (Kigongo ve Reid, 2020; Url36, 2020; Url-37, 2020). Yaklaşık 30 metre yüksekliği ve 8 metre genişliği olan yapı; 
2010 yılında çıkan bir yangında tamamen yok olmuştur, 2013 yılında başlayan yenileme çalışmaları ise devam etmektedir (Şekil 37-38) (Url-38, 2020).

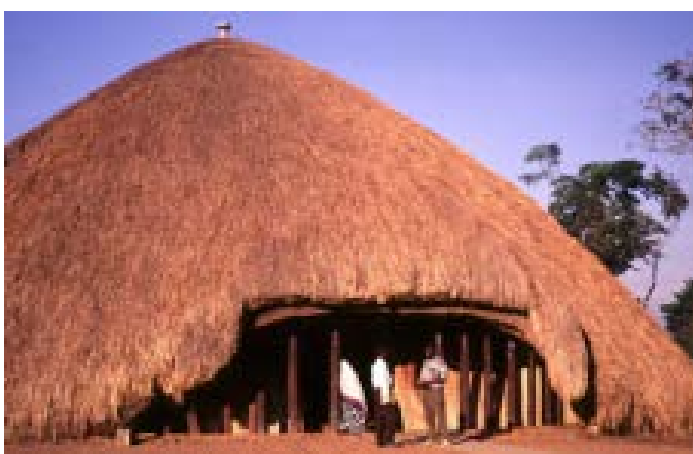

Şekil 37 : Muzibu-Azaala-Mpanga (Url-36, 2020)

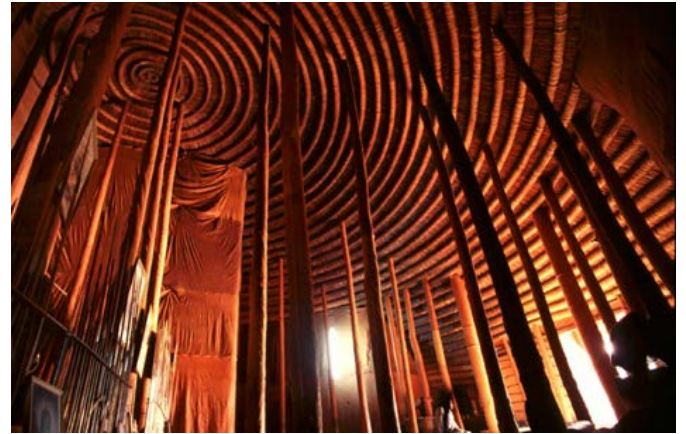

Şekil 38 :Muzibu-Azaala-Mpanga (Url-36, 2020)

\subsection{Amerika kıtası}

Asya ve Afrika'dan sonra en yüksek ağaçların bulunduğu kıta olan Amerika'da 1850 'lere kadar önemli ahşap yapım sistemleri görülmese de, tarihi ve kültürel etkileşimler Avrupa ahşap mimarisinin Amerikan ahşap mimarisini etkilemesini sağlamıştır (Banin vd., 2012; Kniffen ve Glassie, 1966).

Bu başlıkta; Kuzey Amerika'da yer alan ve ahşap taşıyıcı sistem ile inşa edilmiş nitelikli yapılar barındıran Kanada'nın ahşap mimarisi, Amerika Birleşik Devletleri'nin çeşitli bölgelerinde yer alan geleneksel ahşap taşıyıcı sisteme sahip konutlar ve Güney Amerika'da; Şili ahşap kilise mimarisi ile Brezilya'daki tarihi Diamantina kasabasında yer alan ahşap yapılar incelenmiştir (Harita 5-Harita 6). Incelenecek yapılar ve bölgeler seçilirken, önceki bölümlerde olduğu gibi; incelenen yapıların UNESCO Dünya Miras Listesi'nde yer almasına ve/veya bulundukları ülkelerce nitelikli yapılar olarak belirlenmesine dikkat edilmiştir.

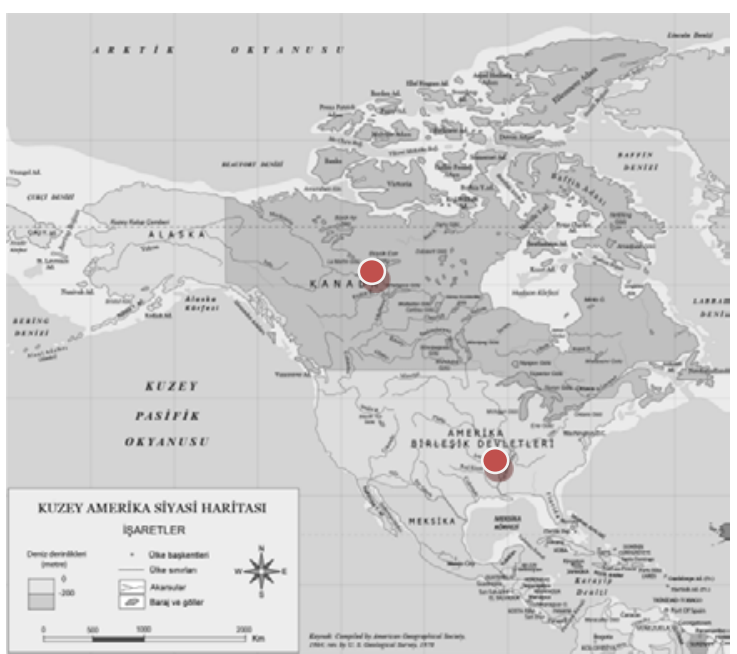

Harita 5: Kuzey Amerika'da ahşap yapım sistemi incelenen ülkeler (Url-2- 2018).

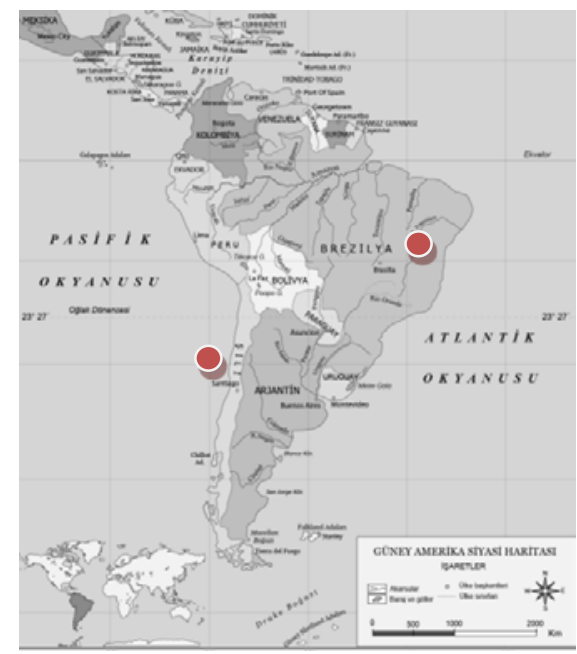

Harita 6: Güney Amerika'da ahşap yapım sistemi incelenen ülkeler (Url-2, 2018)

20. yy başlarına kadar Amerika Birleşik Devletleri, İngiltere ve Fransa mimarilerinin etkisinde gelişen Kanada mimarisi; yerel malzeme, yerel kaynak, teknolojik ve kullanıcı intiyaçları gelişmeleri sayesinde kendi özgün mimari özelliklerine ulaşmıştır (Humphreys ve Skyes, 1980). Bu mimari özellikler günümüzde de, ahşap malzeme ve ahşap taşıyıcı sistem kullanımlarında devam etmektedir (Derinöz, 2006). 
Amerikan ahşap mimarisinde kullanılan ahşap malzemenin birbirine geçmesi ile inşa edilen sistem Kanada'da da belli bir dönem kullanılmış fakat Kanada ahşap mimarisinin yerine alamamıştır (Kniffen ve Glassie, 1966). Kanada ahşap mimarisinin özelliklerini yansıtan Lunenburg'un "Eski Şehir" bölgesi; Kuzey Amerika'daki İngiliz sömürgeleştirme ve yerleşim şekillerinin 240 yıldan uzun süredir korunmuş bir örneğidir (Url-39, 2018; Url-40, 2018). "Pièce sur pièce en coulisse" (geçmeli yığma sistem) ahşap yapım sistemi (Şekil 39-40) ile 18. yy'da inşa edilmiş en az sekiz binanın bulunduğu şehirde; bu yapılar dışında kalan yapılar 19. yy dönemine aittir. Kasabanın mimarlık konusundaki tutumu, 1930'lu yılların başındaki yapım geleneğinin devam etmesini sağlamıştır (Url-39, 2018).

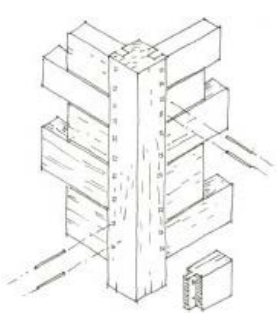

Şekil 39 : Pièce sur pièce en coulisse (Parçalı geçmeli yığma sistem) (Url-41, 2018)

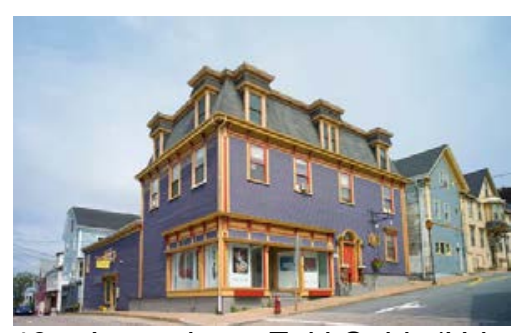

Şekil 40 : Lunenburg Eski Şehir (Url-42, 2018).

1800'lerden önce önemli ahşap yapıların görülmediği Amerika Birleşik Devletleri'nde; ülkeye gelen Avrupalı sömürgeciler ile birlikte ahşap yapılar ve ahşap yapım sistemlerinde de gelişmeler yaşanmıştır (Kniffen ve Glassie, 1966;Pitzer, 1976,Lewandoski, 1985).

Illk olarak Avrupa'da yer alan örneklerine benzeyen ahşap yapılarda zaman içerisinde Amerikan mimari anlayışı gelişmiş ve Balon Çerçeve Sistem- Amerikan Sistemi denilen ahşap yapım sistemi ortaya çıkmıştır (Şekil 41) (Lewandoski, 1985).

Balon Çerçeve Sistem (Balloon Framing); klasik ahşap yapıların aksine ince ve hafif elemanlar ile inşa edilmektedir (Lewandoski, 1985, Cavanagh, 1997; Ohanesyan, 2012).Betonarme ya da taş sürekli temellere sahip yapılarda; duvarları oluşturan elemanlar aynı zamanda dikme görevi görmektedir. Ahşap döşeme kirişleri üzerine yerleştirilen ahşap döşemeler de dikmelere köşelerde çivi ile sabitlenmektedir (Lewandoski, 1985, Cavanagh, 1997; Ohanesyan, 2012).

Amerikan ahşap evleri Avrupa mimarisi ile başlasa da kendi sistemleri oluşmuştur (Şekil 42). Günümüzde de prefabrik sistemler, lamine ahşaplar vb. dâhil olmak üzere ahşap malzemenin özellikle konutlarda kullanımına devam edilmektedir (Fernanda vd., 2015).

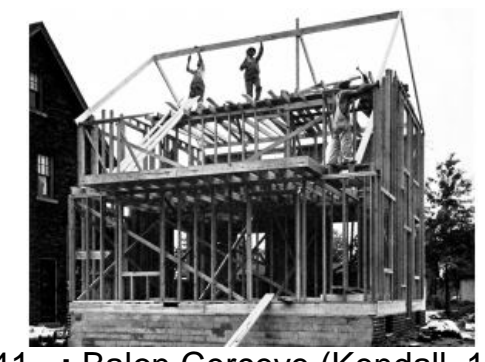

Şekil 41 : Balon Çerçeve (Kendall, 1994).

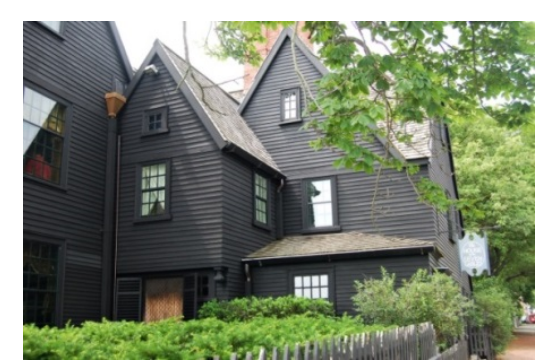

Şekil 42 : Ahşap Ev-New England (Url-43, 2020). 
Güney Amerika'da yer alan ŞiliChloe Adası'nda bulunan ahşap kiliseler; 17.yy'dan günümüze kadar uzanan Latin Amerika dini ahşap mimarisinin önemli temsilcileridir (Ortiz vd., 2014; Costa, 2007). Bölgede yer alan ağaçlar yapım esnasında farklı elemanların yapımında kullanılmıştır; karaçam (fitzroya cupressoides) dış cephe kaplamasında, servi (cupressus)iç mekân kaplamalarında ve taşıyıcılarda vb. (Costa, 2007). Chloe Adası'nda yer alan ve UNESCO Dünya Miras Listesi'nde bulunan 14 kilisenin yapımında toprak ya da metal malzeme neredeyse hiç kullanılmamıştır (Costa, 2007; Url-44, 2020).

Ahşap taşıyıcı sistem ile inşa edilen kiliselerde, yoğun yağıştan korunmak amacı ile dik kırma çatılar kullanılmıştır. Kiliselerin en dikkat çeken kısmı ise; revak, üçgen alınlık ve kuleden oluşan ön cephesidir (Şekil 43-44) (Url-44, 2020).

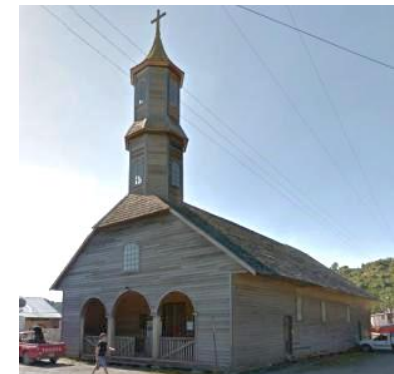

Şekil 43 : San Juan Kilisesi (Url-45, 2020).

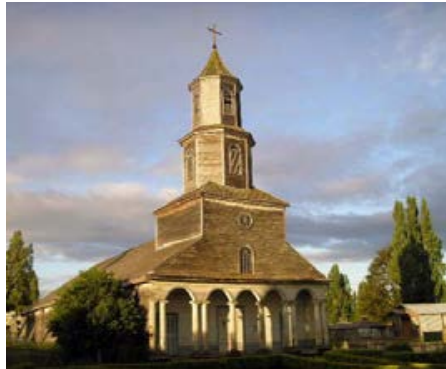

Şekil 44 : Nercon Kilisesi (Url-46, 2020).

Brezilya gibi Latin Amerika ülkelerinde tercih edilen yapı malzemeleri dayanıklı oldukları gerekçesi ile taş, tuğla vb. malzemelerdir. Bu nedenle ahşap yapılar çok sık görülmese de, Avrupa'dan göç alan bölgelerde ahşap taşıyıcı sistem ile inşa edilmiş yapılar görmek mümkündür (Smith, 1937; Maeglin, 1991).

Brezilya'nın Minas Gerais eyaleti de Avrupa'dan göç aldığı için kültürel ve mimari olarak bu göçlerden etkilenmiş bir bölgedir. Burada yer alan Diamantina şehrinde Barok mimari etkileri görülen ahşap yapılar yer almaktadır (Url-47, 2020). Şehirdeki yapılar; taş temeller üzerine ahşap çerçeve sistem uygulanarak inşa edilmiştir. Yapıların duvarlarında ahşap ya da kerpiç malzeme ile dolgu yapılmıştır. Döşemelerde, süslemelerde ve doğramalarda da ahşap yapı malzemesi kullanılmıştır(Url-47, 2020; Torres vd., 2018).

Diamantina şehrinde simgesel olarak öne çıkan yapılar arasında; Casa da Glória, Nossa Senhora do Carmo kilisesi ve Nossa Senhora do Rosário kilisesi bulunmaktadır (Url-47, 2020

Casa da Glória; farklı dönemlerde inşa edilmiş iki ayrı yapıdan oluşmaktadır (Şekil 45). İnşa edildiği dönemde yetimhane ve okul olarak kullanılan iki yapıyı birbirine bağlayan ahşap yaya köprüsü; "Passadiço da Glória" Diamantina şehrinin simgesi haline gelmiştir (Şekil 46) (Url-47, 2020; Url-48, 2020). Yapının taşıyıcı sistemi, zemin döşemeleri, tavan kaplamaları, kapı pencere doğramaları ve yaya köprüsü ahşap malzeme kullanılarak inşa edilmiştir. 

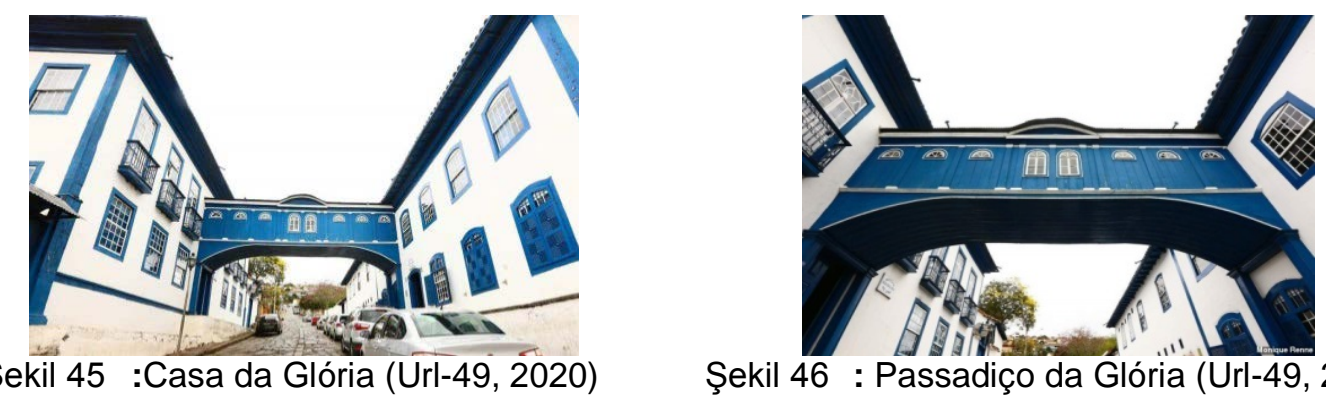

Şekil 46 : Passadiço da Glória (Url-49, 2020).

Nossa Senhora do Carmo kilisesi; 1765 yılında ahşap taşıyıcı sistem ile inşa edilmiş; çeşitli onarımlar ve yenilemeler geçirerek günümüze kadar ulaşmıştır. Minas Gerais eyaletinde yer alan yapılardaki Barok mimari etkisini bu kilisede de görmek mümkündür (Şekil 47) (Torres vd., 2018).

1731 yılında tamamlanan Nossa Senhora do Rosário kilisesi ise; Diamantina'nın en eski kiliselerinden biridir. Ahşap taşıyıcı sistem kullanılarak inşa edilen yapıda; duvarlar ahşap çerçeve sistem arası kerpiç dolgu kullanılarak inşa edilmiştir (Şekil 48) (Url-48, 2020; Medaglia ve Siveria, 2014)

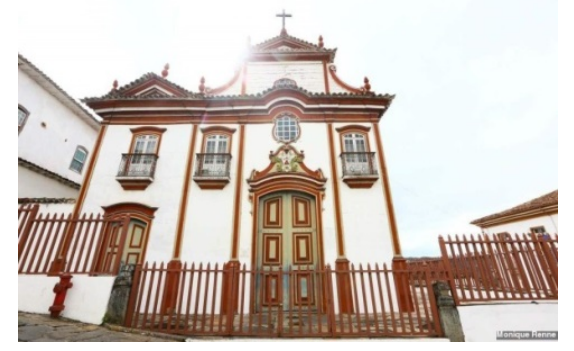

Şekil 55: Nossa Senhora do Carmo (Url-49, 2020).

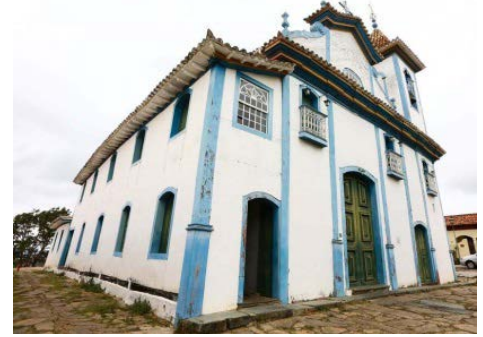

Şekil 56: Nossa Senhora do Rosário (Url$49,2020)$.

\section{DEĞERLENDIRME VE SONUÇ}

Ahşap; ucuz, dayanıkı, pratik ve hafif olması nedeniyle ilk çağlardan beri tercih edilen bir yapı malzemesi olmuştur. Yerel kaynakların mimari tasarım üzerindeki etkisi düşünüldüğünde dünyanın kimi bölgelerinde ahşap yapılara sıklıkla rastlanırken kimi bölgelerinde neredeyse hiç ahşap yapı görülmemektedir.

Anıtsal yapıların inşasında genel olarak tercih edilen taş, tuğla gibi daha dayanıklı olduğu düşünülen yapı malzemeleri varken; ağaçların yüksekliği, dayanıklılı̆ı, genişliği gibi özelliklerinin güçlü olduğu bölgelerde anıtsal yapılarda da ahşabın taşıyıcı sistemde ve yapının diğer elemanlarında kullanıldığı görülmüştür.

Her kıta, ülke hatta aynı ülkede yer alan kentlerde farklı geleneksel yapım sistemleri görülebilmektedir (Tablo 1). Fakat sistemler gelişirken insanların birbirleriyle olan etkileşimleri mimariyi de etkilemiştir. Örneğin; Avrupa'dan göç ederek Amerika'da koloniler oluşturulan bölgelerde Avrupa'nın geleneksel ahşap yapım sistemleri görülmüştür. 
Tablo 1: Çalışmada İncelenen Ahşap Yapım Sistemleri Ahşap Yapılar ve İşlevleri

\begin{tabular}{|c|c|c|c|c|c|}
\hline $\begin{array}{l}\text { BULUNDUĞU } \\
\text { COĞRAFYA/ } \\
\text { ORMAN YOĞUNLUĞU }\end{array}$ & ÜLKE & $\begin{array}{l}\text { YAPI } \\
\text { TÜRÜ }\end{array}$ & $\begin{array}{c}\text { YAPIM } \\
\text { SiSTEMI/ } \\
\text { AHŞAP } \\
\text { ELEMANLAR }\end{array}$ & YAPI ADI/GÖRSELI & YAPI ADI/GÖRSELI \\
\hline \multirow{7}{*}{ ASYA KITASI } & $\frac{\bar{\pi}}{\frac{\pi}{0}}$ & $\begin{array}{l}\text { Anitsal } \\
\text { Yapılar }\end{array}$ & 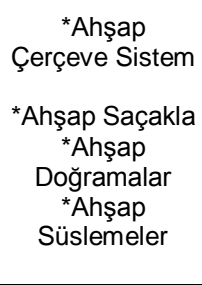 & $\frac{1}{4}$ & \\
\hline & $\frac{5}{0}$ & $\begin{array}{l}\text { Anitsal } \\
\text { Yapılar }\end{array}$ & $\begin{array}{c}\text { *Ahşap Sürekli } \\
\text { Çerçeve Sistem } \\
\text { *Ahşap Kirişli } \\
\text { Çerçeve Sistem } \\
\text { *Ahşap Yığma } \\
\text { Sistem } \\
\text { *Ahşap } \\
\text { Doğramalar } \\
\text { *Ahşap } \\
\text { Süslemeler } \\
\end{array}$ & $\begin{array}{c}\text { Yingxian Ahşap } \\
\text { Pagodası }\end{array}$ & Yingxian Ahşap Pagodası \\
\hline & 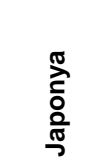 & $\begin{array}{l}\text { Anitsal } \\
\text { Yapılar } \\
\text { Konutlar }\end{array}$ & $\begin{array}{c}\text { *Ahşap } \\
\text { Çerçeve Sistem } \\
\text { *Ahşap } \\
\text { Doğramalar }\end{array}$ & $\frac{1}{\text { minniminum }}$ & \\
\hline & & & Süslemeler & Horyuji Tapınağı & Japonya Konut \\
\hline & $\begin{array}{l}\frac{0}{0} \\
\frac{1}{2} \\
\text { बे } \\
\text { : }\end{array}$ & Konutlar & $\begin{array}{c}\text { *Ahşap } \\
\text { Çerçeve Sistem } \\
\text { *Ahşap } \\
\text { Doğramalar } \\
\text { *Ahşap }\end{array}$ & & \\
\hline & & & susiemerer & Hahoe-Yangdong & Hahoe-Yangdong \\
\hline & 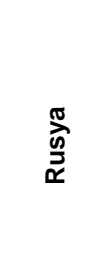 & $\begin{array}{l}\text { Anitsal } \\
\text { Yapılar } \\
\text { Konutlar }\end{array}$ & $\begin{array}{l}\text { *Ahşap } \\
\text { Çerçeve Sistem } \\
\text { *Ahşap Yığma } \\
\text { Sistem } \\
\text { *Ahşap } \\
\text { Doğramalar } \\
{ }^{*} \text { Ahşap } \\
\text { Süslemeler }\end{array}$ & 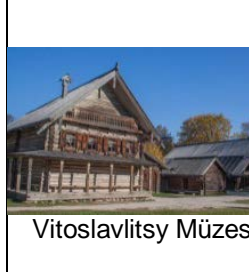 & Kizhi Pagost \\
\hline \multirow[t]{2}{*}{ AVRUPA } & $\begin{array}{l}\frac{\pi}{\frac{\pi}{2}} \\
\frac{\pi}{\frac{\pi}{2}} \\
\frac{\pi}{2}\end{array}$ & $\begin{array}{l}\text { Anitsal } \\
\text { Yapılar } \\
\text { Konutlar }\end{array}$ & $\begin{array}{c}\text { *Ahşap Yığma } \\
\text { Sistem } \\
\text { Ahşap } \\
\text { Çerçeve Sistem } \\
\text { *Ahşap } \\
\text { Doğramalar } \\
\text { *Ahşap }\end{array}$ & Petäjävesi Eski Kilis & Rauma Eski Kent \\
\hline & ¿ & $\begin{array}{l}\text { Anıtsal } \\
\text { Yapılar } \\
\text { Konutlar }\end{array}$ & $\begin{array}{c}\text { *Ahşap Yığma } \\
\text { Sistem } \\
\text { Ahşap } \\
\text { Çerçeve Sistem } \\
\\
\text { *Ahşap } \\
\text { Doğramalar } \\
{ }^{*} \text { Ahşap } \\
\text { Kaplamalar } \\
{ }^{*} \text { Ahşap } \\
\text { Süslemeler }\end{array}$ & Urnes Stave Kilises & Bryygen \\
\hline
\end{tabular}




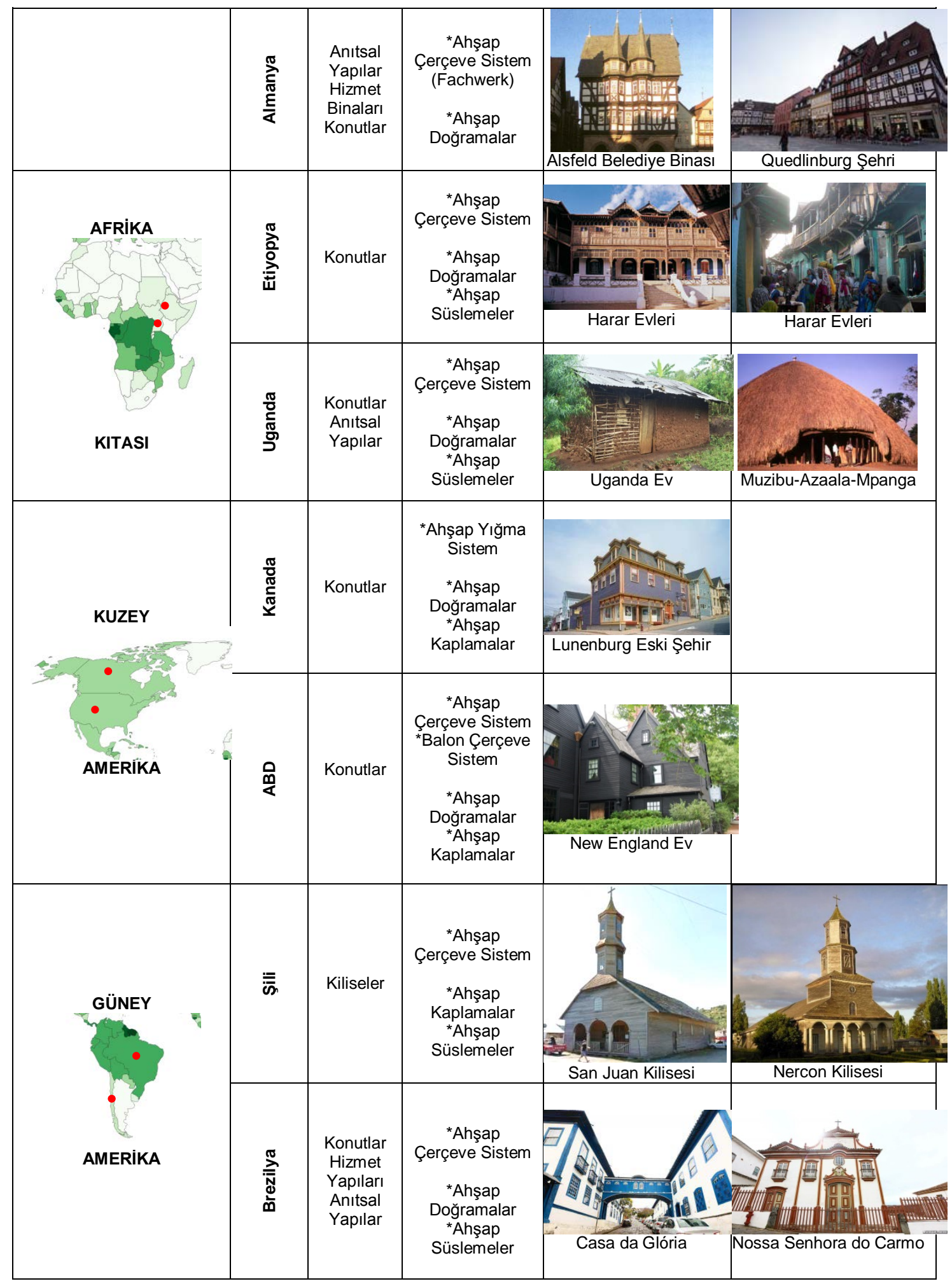

Bu çalışmada incelenen, ahşap taşıyıcı sistem ile inşa edilmiş geleneksel ahşap yapılara bakıldığında; yapılarda taşıyıcı sistem kullanımlarında, mekânsal bölünmelerde, doğramalarda, süslemelerde benzerlikler görmek mümkündür. Benzerlikler görülse de; bir bölgede inşa edilen yapılar o bölgenin, coğrafi, kültürel, siyasi ve teknolojik özelliklerini de yansıttığı için, birbirinden farklı ve yeni sistemler oluştuğu gözlenmiştir. Bu da mimari sistemlere çeşitliliği ve özgünlüğü getirmiştir. 
Asya kıtasında ele alınan ülkelerden Nepal, Çin, Japonya ve Güney Kore'deki ahşap yapıların yapım sistemleri ve cephe özellikleri benzerlik gösterirken; Rusya'da bulunan ahşap yapılar farklılık göstermektedir. Ahşap yığma sistemin daha sık görüldüğü Rusya'da, geleneksel ahşap yapıların cephelerinde de Avrupa etkileri görülmektedir. Avrupa kıtasında incelenen ülkelerde ise; yapım sistemi temelde aynı olsa da; mekânsal ya da statik intiyaçlar doğrultusunda farklılıklar meydana gelmiştir. Yapıların coğrafi konumu ve işlevleri de yapım sistemlerini etkilemiştir. Ahşap yığma sistem ile inşa edilen kütük kiliseler buna örnek olarak gösterilebilir. Afrika kıtası, incelenen ülkeler arasında ekonomik faktörlerden en fazla etkilenen kıtadır. Bu durum yapı malzemelerini etkilemektedir. Ahşap çerçeve sistemin geleneksel olarak kullanıldığı kıtada; dolgu malzemesi olarak saz vb. kolay ulaşılabilen bitkisel ve maliyeti düşük malzemeler kullanılmıştır. Kuzey Amerika'da incelenen ülkelerde farklı yapım sistemleri göze çarpmaktadır. Kanada'da bölgedeki yapılara özgü bir ahşap yığma sistem kullanılırken; ABD'de yer alan konutlarda ahşap çerçeve sistem ve Amerikan sistemi olarak da bilinen Balon çerçeve sistem kullanılmıştır. Güney Amerika'da incelenen ülkelerdeki geleneksel yapılarda ise ahşap çerçeve sistem kullanılmıştır. Konutlar, hizmet yapıları ve dini yapılarda kullanılan ahşap çerçeve sisteme ek olarak cephelerde ve iç mekânlarda da ahşabın sık kullanımı görülmektedir.

Çalışmada incelenen örnekler, dünyanın her bölgesinde geleneksel ahşap yapıların yapım sistemini; iklim, topografya, ekonomi, yapı malzemesi, mekânsal gereksinimler, kültürel etkiler, sosyal ilişkiler ve kullanıcı tercihleri gibi değişkenlerin etkilediğini göstermektedir. Bu değişkenlerden birinin veya birkaçının farklılığı, yapının yapım sistemini ve malzeme kullanımını değiştirmektedir. Örneğin; Almanya'da kullanılan ahşap yapım sistemleri ile Uganda'da kullanılan ahşap yapım sistemleri arasındaki farklılık incelendiğinde, bu değişkenlerin yapım sistemini ne denli etkilediği anlaşılmaktadır. Değişkenlerin benzerliği ise; farklı kıtalarda, aynı sistem kullanılarak yapılar inşa edilmesini sağlamaktadır. Amerika'da yer alan konutların Avrupa'da yer alan konutlarla olan benzerlikleri, farklı kıtalarda aynı taşıyıcı sistem kullanımına örnek olmuştur.

$\mathrm{Bu}$ çalışma; mimari sistemlerin; yaşayan, etkilenen ve gelişen sistemler olduğunu göstermektedir. Günümüzde ise; küreselleşme sonucunda farklı kültürler, coğrafyalar arasındaki etkileşimin artması ve ahşap endüstrisinde yaşanan gelişmelerin de etkisi ile inşa edilen ahşap yapılarda daha fazla benzerlik gözlenmektedir. Geleneksel ahşap yapım sistemlerinin günümüz teknolojisi ile birlikte kullanılmasının, daha dayanıklı, ucuz, işlevsel ahşap yapıların inşa edilmesini sağlayacağı düşünülmektedir. Çalışmanın, ahşap taşıyıcı sistemler ile ilgili kaynaklara katkı sağlaması beklenmektedir. 


\section{KAYNAKLAR}

Aytüre, Selma, Aydoğdu, Semra, Berki, Ömer, "Hansa Birliği (Avrupa Birliği'nin sonu da Hansa Birliği gibi mi olacak?)", The Journal of Academic Social Science Studies, 58: 523-541, 2017.

Ayverdi, Aligül, “Japonya mimarlığı ve çağdaş mimarlık”. Mimarlık Dergisi, 5(4) 21-24, 1967.

Banin, L., Feldpusch T.R., Phillips, O. L., Baker, T. R., Lloyd, J., "What controls tropical forest architecture? Testing enviromental, structural and floristic drivers." Global Ecology and Biageography, $21,1179-1190,2012$.

Bilici, Serdar, Ahşap konut üretim sistemleri; Almanya örneği, Selçuk Üniversitesi, Fen Bilimleri Entitüsü, Yüksek Lisans Tezi, 131 s, Konya, 2006.

Bodach, Susanne, Lang, Werner, Hamhaber Johannes. "Climate responsive building design strategies of vernacular architecture in Nepal." Energy and Buildings 81: 227242, 2014.

Brumfield, William Craft, "Style Moderne and the Rediscovery of the Wooden Architecture of the Russian North: the Photographic Connection". Journal of Siberian Federal University. Humanities \& Social Sciences, 9 (10), 2383-2397, 2016.

Bye, Mette, Histories of architectural conservation five case studies on the treatment of Norwegian vernacular heritage buildings circa 1920-1980, Norwegian University of Science and Technology Faculty of Architecture and Fine Art Department of History, Architectural Design and Technology, Doktora Tezi, Trondheim, 681 s, 2010.

Cavanagh, Ted, "Balloon Houses: The Original Aspects of Conventional Wood-Frame Construction Re-examined", Journal of Architectural Education, 51:1 5-15, 1997.

Chen, Zhiyong, Zhu, Enchun, Lam, Frank, Pan, Jinglong, "Structural performance of Dou-Gong brackets of Yingxian Wood Pagoda under vertical load - An experimental study", Engineering Structures 80: 274-288, 2014.

Cho, In Souk, "An Overview of Korean wooden architecture. İnternetional Conference Of Sustainable Building Asia." $2013 . \quad$ https://www.irbnet.de /daten/iconda/CIB_DC26543.pdf), (Erişim Tarihi: 20 Temmuz 2018).

Choi, Yoon Kyung, "The spatial structure of power: traditional villages and houses in Korea." Environment and Planning B: Planning and Design 30: 589-603, 2003.

Costa, L. Berg, "Restauración en Chiloé (Chile):la Iglesia de Castro". Apuntes. 20 (1): 126-141, 2007.

Derinöz, Cengiz, Wood frame house construction process and performance investigation. İstanbul Teknik Üniversitesi, Fen Bilimleri Enstitüsü, Yüksek Lisans Tezi, $82 \mathrm{~s}$, İstanbul, 2006. 
Ejiga, Opaluwa, Paul, Obi, Cordelia, O. Osasona, "Sustainability in traditional African architecture: a springboard for sustainable urban cities". Sustainable Futures: Architecture and Urbanism in the Global South, Uganda, 2012.

Espedal, Knut Jonas, "From stone to Norwegian wood", Int. J. Comp. Meth. and Exp. Meas., 5 (6): 985-996, 2017.

Fernanda, Maria, Mallo, Laguarda, Espinoza, Omar, "Awareness, perceptions and willingness to adopt Cross-Laminated Timber by the architecture community in the United States", Journal of Cleaner Production 94, 198-210, 2015.

Forest products from Latin America An Almanac Of The State Of The Knowledge And Thebstate Of The Art, Maeglin, Robert, United States Forest Service Department of Agriculture, 151s, 1991.

Griffin, Brett, Barlas, Robert, Yong, Jui Lin, Uganda. Cavendish Square Publishing, 144s, 2019.

Heikkila, Jari, "Moisture damage in Finnish wooden houses", Journal of Building Appraisal,1(4): 331-343. 2005.

Humphreys, Barbara. A., Sykes, Meredith, The Buildings Of Canada A Guide To Pre20th-Century Styles İn Houses, Churches And Other Structures, The Readers Digest Association, Montreal, 12 s, 1980.

Kendall, Stephen, "The Entangled American House", Blueprints, National Building Museum, 12s, 1994

Khodakovsky, Evgeny, Wooden Church Architecture of the Russian North, Regional schools and traditions (14th-19th centuries). Routledge,176 s. 2015.

Kigongo, Remigius, Reid, "Andrew, Local communities, politics and the management of the Kasubi tombs, Uganda", World Archaeology, 39:3, 371-384, 2007.

Kim, Do-Kyoung, "The natural environment control system of Korean traditional architecture: Comparison with Korean contemporary architecture". Building and Environment. 41: 1905-1912, 2006.

Kisternia, M., 2018. Kizhi Açık Hava Müzesi'ndeki Tarihi Ahşap Yapıların Korunması, Ahşap Yapılarda Koruma Ve Onarım Sempozyumu 6 Bildiri Kitabı, İstanbul.

Kniffen, Fred, Glassie, Henry, Building in Wood in the Eastern United States: A TimePlace Perspective, American Geographical Society, 56: 40-66, 1966.

Larsen, Knut Einar., Marstein, Nils., "Conservation of historic timber structuresan ecological approach." 2016. http://openarchive.icomos.org/1656/1/Conservation_ of_Historic_Timber_Structures-2.pdf, (Erişim Tarihi: 30 Haziran 2018).

Lewandoski, Jan. Leo, "Transitional Timber Framing in Vermont, 1780-1850", APT Bulletin, Vol. 26(2/3) 42-50s, 1995.

Mainicheva, A.Y., Skobelev, S.G., Berezhenko, D.Y., "Reconstruction of Wooden and Earthen Buildings in 17th to 18th Century Russian Forts in Siberia: The Case of the 
Sayansky Ostrog", Archaeology, Ethnology \& Anthropology of Eurasia, 46(4) 100-108, 2018.

Medaglia, Juliana, Siveria, C. Eduardo., "Conhecer Para Respeitar: Patrimônio E Cidadania Em Diamantina", Participação, n. 23/24, p. 93-100,. 2014.

Ohanesyan, Serli, D., Ahşap Platform Çerçeve Yapıların Yatay Kuvvetler Karşısındaki Davranışları Ve Alınması Gereken Önlemler. Yıldız Teknik Üniversitesi, Fen Bilimleri Enstitüsü, Yüksek Lisans Tezi, 244 s, İstanbul, 2012.

Ortiz, Rodrigo, Parraga, Mario, Navarrete, Jose, Carrasco, Ivo, Vega, Eduardo, Ortiz, Manuel, Herrera, Paula, Jurgens, Joel. A., Held, Benjamin. W., Blanchette, Robert. A., "Investigations of biodeterioration by fungi in historic wooden churches of Chiloé, Chile", Microb Ecol, 67 (3): 568-575,2014.

Peters, James Sedalia., "Finnish wooden towns: urban design in wood", 2006. http://support.sbcindustry.com/Archive/2006/aug/Paper_088.pdf, (Erişim Tarihi: 10 Haziran 2018).

Pitzer, Elizabeth Neal, Virginia architecture in the seventeenth century :the medieval style, University of Richmond, Tez Çalışması, 45s, 1976.

Que, Ze-li., Li, Zhe-rui., Zhang, Xiao-lan., Yuan, Zi-ye., Pan, Biao,. "Traditional wooden buildings in China." Wood in Civil Engineering, Chapter (10):197-221, 2017.

Radzuan, Syahrul. Mat, Ahmad, Yahaya, Fukami, Naoko, Inho, S., "Incentives mechanism for the conservation of traditional villages in Japan and South Korea". The Sustainable City VIII, 2: 1213-1224, 2013.

Roser, M., 2017. Forests. https://ourworldindata.org/forests, (Erişim tarihi: Haziran 2018).

Sangiorgi, Franco., "The vernacular rural heritage: from the past to the future", Futuropa, 1: 4-6. 2008.

Sharma, Keshab, Pokherel, Bigul, 2017. "Performance of heritage structures during the Nepal earthquake of April 25, 2015." Journal of Earthquake Engineering, www.tandfonline.com/loi/ueqe20.

Smith, Robert, "The Colonial Architecture Of Minas Gerais In Brazil", Art Bulletin, Vol 21(2), 110-159, 1937.

Soikkeli, Anu, Koiso-Kanttila, Jouni, "Kärsämäki Church in Finland - modern language of form combined with old techniques and craftsmanship", Structural Analysis of Historical Constructions, 2006. http://www.hms.civil.uminho.pt /sahc/2006/0479.pdf, (Erişim Tarihi: 30 Haziran 2018).

Suominen-Kokkonen, Renja, "Studies of wooden churches in Finland: Josef Strzygowski and Lars Petterson. Tahiti : taidehistoria tieteenä", 2016. http://tahiti.fi/042016/tieteelliset-artikkelit/studies-of-wooden-churches-in-finland-josef-strzygowski-andlars-petterson/, (Erişim Tarihi: 30 Haziran 2018). 
Surur Sany, Amrela, Etiyopya geleneksel Harar evlerinin analizi ve Harar evlerinin değişim ve dönüşümü üzerine modernleşmenin etkisinin irdelenmesi. Kocaeli Üniversitesi, Sosyal Bilimler Enstitüsü, Yüksek Lisans Tezi, 107 s, Kocaeli, 2015.

Tokyay, Vedat., Mimarlık Ve Ahşap İlişkileri, Mimarlık Vakfı İktisadi İşletmesi, İstanbul, 238 s, 2017.

Torres, Ana. Clara, Porto, Thiago., Junior, A. Pires., Gomes, R. Cesar., "Prestauração De Estrutura Em Madeıra Da Igreja Nossa Senhora Do Carmo Em Diamantina Mg: Estudo De Caso", REEC - Revista Eletrônica De Engenharia Civil, 15(1). 2018.

Url-1:http://www.earth-auroville.com/ world_techniques_introduction_en.php. (Erişim Tarihi: 30 Haziran 2018).

Url-2: http://cografyaharita.com/dunya_siyasi_haritasi.html, (Erişim Tarihi: 18 Temmuz 2019).

Url-3:http://www.ourglobaltrek.com/namaste-kathmandu/, (Erişim Tarihi: 18 Temmuz 2018).

Url-4:http://ecs.com.np/art/kasthamandap-temple-a-centuries-old-architecturalmarvel,(Erişim tarihi: 24 Nisan 2018).

Url-5: http://www.columbia.edu/itc/ealac/V3613/taian/index.html, (Erişim tarihi: 25Nisan 2018).

Url-6:https://whc.unesco.org/en/list/1324/documents/, (Erişim Tarihi: 18 Temmuz 2018).

Url-7:whc.unesco.org/en/documents/155444, Ko Hon Chiu Vincent, (Erişim Tarihi: 18 Temmuz 2018).

Url-8:http://whc.unesco.org/en/documents/114861, Seong Joon Cho, (Erişim Tarihi: 18 Temmuz 2018).

Url-9: https://www.unece.org/fileadmin/DAM/timber/h3/Warsaw\%20doc/Documents/ Russian\%20forests.doc, (Erişim Tarihi: 18 Haziran 2020).

Url-10:https://russiatrek.org/blog/culture/the-museum-of-folk-wooden-architecturevitoslavlitsy/, (Erişim Tarihi: 18 Haziran 2020).

Url-11:http://www.moscow.info/parks/ostankino-park.html, (Erişim Tarihi: 18 Haziran 2020).

Url-12:https://www.nationalgeographic.com/travel/destinations/europe/russia/kizhipogostworld-heritage-site/, (Erişim Tarihi: 18 Haziran 2020).

Url-13:http://kizhi.karelia.ru/gallery/udalov, (Erişim Tarihi: 18 Haziran 2020).

Url-14:http://www.unece.org/forests, (Erişim tarihi:20 Haziran 2018).

Url-15:https://whc.unesco.org/en/list/582/documents/, (Erişim tarihi:20 Haziran 2018). 
Url-16:https://whc.unesco.org/en/list/584/documents/,(Erişim tarihi:20 Haziran 2018).

Url-17:http://www.petajavesi.fi, (Erişim Tarihi: 30 Haziran 2018).

Url-18:Thompson, N., whc.unesco.org/en/documents/111320 Nick, (Erişim Tarihi: 30 Haziran 2018).

Url-19:Vincent, K.H., Web Sayfası: whc.unesco.org/en/documents/143826, (Erişim Tarihi: 30 Haziran 2018).

Url-20:https://whc.unesco.org/en/list/59/documents/, (Erişim Tarihi: 30 Haziran 2018).

Url-21:whc.unesco.org/en/documents/107984, (Erişim Tarihi: 30 Haziran 2018).

Url-22:https://whc.unesco.org/en/list/58/documents/, (Erişim Tarihi: 30 Haziran 2018). Url-23:Our Place, whc.unesco.org/en/documents/130607, (Erişim Tarihi: 30 Haziran 2018).

Url-24:Our Place, whc.unesco.org/en/documents/130609, (Erişim Tarihi: 30 Haziran 2018).

Url-25:https://whc.unesco.org/en/list/535/documents/, (Erişim Tarihi: 30 Haziran 2018). Url-26: https://hbz-nord.de/informationsdienst-holz/,R07_T03_F01_Erneuerung_von_ Fachwerkbauten_2004.pdf, (Erişim Tarihi: 30 Haziran 2018).

Url-27: https://www.haus.de/bauen/fachwerkhaus-daemmen-tipps-zur-sanierung, (Erişim Tarihi: 30 Haziran 2018).

Url-28:Schnarr, T., whc.unesco.org/en/documents/129984, (Erişim Tarihi: 30 Haziran 2018).

Url-29: Brecht, E., whc.unesco.org/en/documents/110791, (Erişim Tarihi: 30 Haziran 2018).

Url-30: www.africavernaculararchitecture.com, (Erişim Tarihi: 30 Haziran 2018).

Url-31:https://whc.unesco.org/en/list/1189/documents/, (Erişim Tarihi: 2 Temmuz 2018).

Url-32:Santelli, S., whc.unesco.org/en/documents/113682, (Erişim Tarihi: 2 Temmuz 2018).

Url-33:Leeuw, A., whc.unesco.org/en/documents/133094, (Erişim Tarihi: 2 Temmuz 2018).

Url-34:http://www.face-music.ch/artuganda/uganda_artwork_en.html, (Erişim Tarihi: 2 Temmuz 2020).

Url-35:https://twitter.com/sadabkitatta79/status/781492117222854657, (Erişim Tarihi: 2 Temmuz 2020). 
Url-36:http://whc.unesco.org/uploads/nominations/1022.pdf, (Erişim Tarihi: 2 Temmuz 2020).

Url-37:http://www.kasubitombs.org/en/general/index.php, , (Erişim Tarihi: 2 Temmuz 2020).

Url-38:www.jcic-heritage.jp/en/project/africa_uganda_201411/, (Erişim Tarihi: 2 Temmuz 2020).

Url-39:https://whc.unesco.org/en/list/741/documents/, (Erişim Tarihi: 2 Temmuz 2020).

Url-40:https://www.explorelunenburg.ca, (Erişim Tarihi: 2 Temmuz 2020).

Url-41:http://www.infopatrimoine.ca, (Erişim Tarihi: 2 Temmuz 2020).

Url-42:Vincent, K. H. C., whc.unesco.org/en/documents/133847, (Erişim Tarihi: 2 Temmuz 2020).

Url-43:Graves, $\quad$ A., $\quad$ https://newengland.com/today/living/homes/new-englandarchitecture/, (Erişim Tarihi: 2 Temmuz 2020).

Url-44:https://whc.unesco.org/en/list/971/documents/, (Erişim Tarihi: 2 Temmuz 2020).

Url-45:https://virtualglobetrotting.com/map/church-of-san-juan-bautista-dalcahue/,

(Erişim Tarihi: 2 Temmuz 2020).

Url-46:Linao, L., http://whc.unesco.org/en/documents/113889, (Erişim Tarihi: 2 Temmuz 2020).

Url-47: https://whc.unesco.org/en/list/890/documents/, (Erişim Tarihi: 2 Temmuz 2020).

Url-48:http://www.minasgerais.com.br, (Erişim Tarihi: 2 Temmuz 2020)

Url-49:Renne, M., https://guia.melhoresdestinos.com.br/fotos-diamantina-204-2567p.html, (Erişim Tarihi: 2 Temmuz 2020)

Voyce, A., 1957. National elements in russian architecture. http://online.ucpress.edu/jsah/article-pdf/16/2/6/171082/987741.pdf, (Erişim Tarihi: 18 Haziran 2020).

Yamato, Satoshi, "The tradition of wooden architecture in Japan", 2006. http://www. nara.accu.or.jp/english/img/elearning/2006/tradition.pdf, (Erişim tarihi: 25 Nisan 2018).

Yasuhara, Morihiko, Sakiyama, Tadahiko, "Characterization of space around Japanese traditional buildings: transitions of layout plan and meaning ofspace of darkness inside wooden temples", WIT Transactions on the Built Environment, 2006.

Yasuhara, Morihiko, Sakiyama, Tadahiko, Libuchi, Koichi, "Characterization of space around Japanesetraditional buildings: "Visible Music" on theapproach to Horyuji Temple, Saiin(West Compound)" WIT Transactions on the Built Environment, 2007. 